\title{
The interpretive dimension of economics: Science, hermeneutics, and praxeology
}

\author{
Don Lavoie
}

Published online: 20 January 2011

(C) Springer Science+Business Media, LLC 2011

Keywords Hermeneutics · Praxeology · Interpretive dimension · Gadamer · Schutz

\section{Introduction}

A crisis of the method of economic thinking is taking shape. The question arises, to what extent the style of economic thought which has been predominant for about half a century, at least in the Western World, can do justice to the problems of human action in a rapidly changing world, and, in particular, in a tempestuous epoch.

Ludwig M. Lachmann (1984, p. 1)

This essay confronts three bodies of methodological literature with one another: the growth of knowledge literature on the methods of the sciences in general, the continental philosophy known as "hermeneutics" (or the science of interpretation) on the methods of the social sciences, and the methodology that the Austrian school economist Ludwig von Mises called "praxeology" (or the science of human action) on the methods of economics in particular. The upshot of this confrontation will be that all three bodies of literature argue for what will be called an "interpretive" approach to scientific explanation. My aim is to introduce to philosophers and economists two specialized methodological literatures that go by such obscure names as hermeneutics and praxeology by using themes from a body of literature with which both philosophers and economists are quite familiar, the growth of knowledge tradition.

The growth of knowledge literature gives us important insight into the nature of human knowledge in general but unfortunately confines its attention to the natural sciences. The hermeneutics literature fills this gap with important explanations,

D. Lavoie $(\bowtie)$

George Mason University, Fairfax, VA 22030, USA

e-mail: vstorr@gmu.edu 
broadly consistent with the central message of the growth of knowledge approach, of those aspects of knowledge that are particularly important to the social sciences. But hermeneutics itself, at least in its modern revivals, fails to address its insights about social scientific methods to one of the most important of the social sciences, economics. The methodology Austrian economists call praxeology can be seen in turn as exemplary of a hermeneutical approach to economics. And all three of these methodological literatures lend support to a common conclusion that neoclassical economics is badly in need of reform and that this reform could be described as a restoration of the interpretive dimension to our economic discourse.

The style of modern neoclassical economics which Ludwig Lachmann labels "late classical formalism," and which Austrian economists frequently lament, may be attributable to an intrusive methodological bias against the "interpretive" dimension of economics. This bias became dominant relatively late in the history of economics (Lachmann dates it from about the 1930s) and can be seen as an unfortunate symptom of the philosophical perspective that the Austrian economists often called positivism and that will here be called objectivism. Objectivism, I contend, has led to an inappropriate devaluation of the very features of neoclassical economics which have been best advanced in its Austrian branch. These "interpretive" features of economic explanation will be elaborated below and for now will be simply named the historical (both history proper and history of ideas), linguistic, narrative, dialogical, perspectivistic, tacit, and sociological aspects of economic explanation. ${ }^{1}$ Objectivism has been so powerful an influence in economics that, even though many of the most prominent economists of the 1930s such as Keynes and Knight stressed the importance of many of these interpretive aspects of explanation, the dominant schools of thought that claim to descend from Keynes and Knight have come to seriously neglect this dimension. Fortunately, within philosophical circles objectivism has now been largely repudiated, most notably in the famous "growth of knowledge" literature. ${ }^{2}$ But before its demise, objectivism left a profound legacy of what could be called scientifically inappropriate prejudices in all the disciplines it touched, including, besides economics, psychology, political science, history, sociology, and linguistics. ${ }^{3}$ Now, reinforced by the growth of knowledge tradition, as well as several other developments in contemporary philosophy, the methodo-

\footnotetext{
${ }^{1}$ Each of these related aspects of the interpretive dimension of explanation will be elaborated throughout parts 2 and 3 of this essay and are specifically noted in footnote numbers 11, 14, 21, 26, and 30 .

${ }^{2}$ By the growth of knowledge literature I mean the writings of Popper (1964; 1965; 1972), Lakatos (1978), and Lakatos and Musgrave (1970), Kuhn, and Feyerabend (1975). Closely related and complementary discussions of the nature of science in general can be found in the following works: Barnes (1982), Gelwick (1977), Hattiangadi (1983), Hesse (1980), Polanyi (1958a; 1969), Polanyi and Prosch (1975), Toulmin (1972), and Weimer (1980).

${ }^{3}$ See Ions (1977) which pinpoints many of these objectivistic biases among economists, game theorists, political scientists, cliometricians, jurimetricians, psychologists, linguists, and others. His remarks about economics are particularly interesting:
}

[I] t does strike an outsider, after a fresh, if incomplete immersion in the literature, that economics seems more than ever likely to separate into two distinctive sub-disciplines, the one formal, axiomatic, deductive, and belonging peculiarly to the world of pure mathematics; the other stressing that economics is an applied social science, or it is nothing. The second group cannot be dismissed as innumerate... but they clearly find it more congenial to locate their work in an intellectual tradition cognate to other disciplines, especially philosophy and politics... (1977, pp. 50-51). 
logical grip of objectivism is loosening in most of these disciplines and their interpretive dimensions are becoming correspondingly enriched.

Economists have not, luckily, taken their objectivism so seriously that it has prevented them from understanding the real world or from improving upon our theoretical and empirical knowledge. It may be the case, however, that the progress of knowledge in our discipline has been retarded by this bias against the interpretive dimension. We have been consistently misrepresenting the nature of economic explanation. As McCloskey pointed out, though it is usually economists' interpretive skills that guide them when they think about the economy, and it is only the explanations they themselves find interpretively compelling that persuade them, it is only the econometrics or the mathematical proofs that they consider the scientific part of their work. ${ }^{4}$ Theories, we solemnly teach our students, must be accepted or rejected only on the basis of their predictive accuracy or mathematical rigor. A mere "interpretation" of an historical episode cannot compete effectively for space in our contemporary journals with an econometric test of a specific quantitative model. Nor can a mere interpretation of the meaning of an economic theory compete on equal terms with the rigorous development of a new formal model. There remains in economics a strong "objectivist bias" against the qualitative/interpretive aspects of research in favor of the quantitative/predictive aspects. Worst of all the objectivist bias has made economics boring.

Several minority schools in the contemporary profession-from Marxists, institutionalists, and post-Keynesians to supply siders - may be said to be relatively free of this objectivist bias compared with mainstream neoclassicism. Neoclassical economists, however, seem to view these schools as if they were Barbarian Hoards at the Gates of Economic Science, threatening to undermine the positive standards, and thus the most fundamental principles, of microeconomics. ${ }^{5}$ While this fear is certainly exaggerated, many mainstream economists may legitimately wonder whether the progress which was made as a result of the marginalist/subjectivist revolution in micro could be lost to the anti-theoretical historicism of institutionalists, or the predominantly macro perspectives of supply siders and postKeynesians, or the complete reversion to nineteenth century economics in the objective value theory of Marxism. The basic truths we economists teach our principles students about supply and demand and the logic of choice may seem, to many of us, to be genuinely threatened by the growing dissatisfaction with neoclassical microeconomics.

On the other hand, the flourishing of such diverse schools of thought may be seen as a hopeful sign that the profession is starting to stir, if not yet awaken, from its

\footnotetext{
${ }^{4}$ Hahn and Hollis (1979, p. 1) observe that in economics "Popper's picture of science as conjectures and refutations has been widely admired and endorsed but not seen as a threat to the hopes of a positive economics grounded on orthodox Positivist tenets. The upheaval caused by Quine's pragmatism, Kuhn's paradigms, and other more recent bouleversements has yet to send more than a tremor through the temple." Aside from the brilliant article on "The Rhetoric of Economics" by Donald McCloskey (1983), and the Caldwell book, economists have generally failed to appreciate the radical significance for their work of the growth of knowledge literature.

${ }^{5}$ McCloskey (1983, pp. 509-510) ascribes this fear of a breach in the "wall against irrational and authoritarian threats to inquiry" to a "low opinion of the free play of ideas."
} 
methodological slumber. Economics today is, as Lachmann put it, in tempestuous season. It comes more and more to reflect an interesting rivalry among divergent perspectives, each begging for clear interpretation from the others, rather than a monolithic system of objectively "tested" quantitative relationships which neither asks for nor seems to require any interpretation. As such, it appears increasingly likely not only that each of the minority schools will have to extend the interpretive dimension of their research, in order to explain in plain language what their theory is supposed to mean, but also that the neoclassical mainstream may be compelled to do so if it intends to defend those cherished principles of choice theory against the "hoards." When it does, it may find that of the three great branches of marginalist/ subjectivist economics that emerged in the 1870 s, the interpretive side of economics has been best advanced in the tradition that followed Menger rather than Walras or Jevons.

The thesis of this paper will be that economists should free our research from the objectivist bias and correspondingly alter our style of scientific discourse. Economists should, in light of the growth of knowledge and hermeneutics literatures, restore to its pre-objectivist status the interpretive dimension of our work. Economics will have to become, once again, more a forum for the open contention among interpretations of theory and history, than the kind of simulated laboratory for the objective testing of hypotheses, or ivory tower for the proof of mathematical theorems, it is now. This challenge to neoclassical economics is not an external but rather an immanent criticism. It does not urge the overthrow of the basic analytical content of modern economics as it arose from the marginalist/subjectivist revolution in the 1870s. The conclusion at which this paper aims is a demonstration that in the Austrian branch of neoclassicism, we can discover a way to reinstate an interpretive dimension into the style of economic discourse without opening the gates to the antimicroeconomic "hoards."

The subsequent argument will be organized into three stages representing a progressive narrowing of focus, moving from science, to social science, and then to economics. These three stages of argument can be usefully summarized by reference to three recent books on methodology that provide successive parts of an argument on behalf of the Austrian variant of neoclassical economics. T.W. Hutchison's The Politics and Philosophy of Economics, Marxians, Keynesians and Austrians (1981), although broadly very supportive of the contributions of the Austrians, interprets Mises's praxeology as a pre-Popperian methodology that has been made obsolete by the growth of knowledge literature. Bruce Caldwell's Beyond Positivism: Economic Methodology in the Twentieth Century (1982) argues that, contrary to Hutchison, praxeology is fully consistent with the valid message of Popperianism and with the growth of knowledge literature in general. Richard J. Bernstein's Beyond Objectivism and Relativism: Science, Hermeneutics, and Praxis (1983), although it contains no specific references to economics or Austrian methodology, can be seen as showing why an approach like praxeology should be considered a post-Popperian methodology for economics, a methodology that is consistent with, but goes beyond, that of the growth of knowledge literature.

Despite Hutchison's rather favorable assessment of the "essential Austrian message of individualism and subjectivism" (1981, p. 224), he objects strenuously to what he sees as a "pretense of knowledge" in some Austrian writings, a pretense 
with which the growth of knowledge literature is in "an absolutely fundamental philosophical clash” (1981, p. 229). Hutchison, for example, ridicules Mises's and Wieser's notion that one of the primary sources of knowledge for economics is "introspection," to which Hutchison disdainfully refers as some sort of "infallible inner voice."6 Methodologies like Mises's and Wieser's, he argues, depend on private knowledge and thus are in principle unfalsifiable. Therefore, Hutchison concludes, according to the basic ideas stemming from the growth of knowledge literature, praxeology is unscientific dogmatism.

Bruce Caldwell, on the other hand, offers a more sympathetic reading of Austrian methodology, and argues that the usual attacks on it, including Hutchison's, are inadequate. Instead of applying Popperian falsificationist standards, which Caldwell finds neither as clear-cut as Hutchison seems to think, nor as appropriate to addressing the Austrians' argument, Caldwell (1982, pp. 128-135) provides an outline of what a critique that "meets the Austrians on their own ground" would look like:

A different route for criticizing praxeology makes use of the notion of theory choice.... On what grounds do we choose among competing theories?....But we find in the Austrian literature no discussion of theory choice. The reason is not difficult to discover: since the Austrian system is presumably founded on a priori true postulates, it is either true or false... However [this stance] does run into problems of its own, chiefly because a priori true postulates (and the systems that follow from them by deduction) at least seem capable of multiplication.

Thus Caldwell urges the Austrians to specify more definite criteria for theory choice than they have, but unlike Hutchison he finds nothing in the Austrians' methodology that renders it inherently unscientific. The growth of knowledge literature teaches us to adopt an attitude of tolerance with respect to schools of thought which may apply different criteria of theory choice than does mainstream neoclassical economics.

For Hutchison, the chief lesson economists should learn from the growth of knowledge literature is that we should strive for more falsifiable theories, from which he concludes that methodologies like those of some Austrians are to be rejected. For Caldwell, on the other hand, the lesson is that economists should be more tolerant of divergent approaches and should promote a methodological pluralism, from which he concludes that methodologies like those of these same Austrians ought to be taken more seriously. Evidently these conflicting assessments of Austrian methodology are traceable to diametrically opposed interpretations of the growth of knowledge literature. To resolve their conflicting interpretations of this literature, the Hutchison and Caldwell books need to be supplemented by a third book on methodology, Richard J. Bernstein's Beyond Objectivism and Relativism: Science, Hermeneutics, and Praxis, which offers an intriguing comparison and

\footnotetext{
${ }^{6}$ Hutchison (1981, p. 206) was borrowing this unfortunate phrase "inner voice" from one of the Austrian school's main contributors, Friedrich von Wieser $(1928$, p. 8). The phrase "pretense of knowledge" was borrowed from another famous Austrian, F.A. Hayek.
} 
integration of the growth of knowledge tradition with "hermeneutics."7 Bernstein's analytical procedure is to juxtapose, and as far as possible, integrate together three literatures including both the growth of knowledge and hermeneutics literatures examined here as well as a Marxian perspective not to be considered here, namely Habermas's philosophy of "Praxis." As the title of this paper suggests, my analytical procedure will be to extend Bernstein's integrative effort, and in particular apply it, as he did not, to economics, by substituting praxeology for praxis. The scholarly tradition that traces back to Menger's "subjective" value theory in economics ought to be at least as conducive to hermeneutical and growth of knowledge perspectives as is the tradition that traces back to Marx's "objective" theory of value. ${ }^{8}$

Bernstein's work discusses (and is an example of) a recent flourishing of interest, within philosophy and most of the social sciences, in the continental tradition of hermeneutics, but this development has unfortunately left economics almost untouched. It reveals a characteristic of the whole modern hermeneutic movement when the editors of an excellent new book of readings (Rabinow and Sullivan 1979, p. 10) declare that their aim is to present modern hermeneutics to "a wide audience" and then list historians, sociologists, anthropologists, psychologists, historians of religion, scientists, and philosophers. Economists might have earned this neglect but economics doesn't deserve it. In fact the pioneers of hermeneutics such as Dilthey and Weber had a great interest in economic issues, and the general methodological lessons hermeneutics can teach social scientists seem eminently applicable to economics. It is from insights into the nature of human understanding arising in this tradition that a path for the adjudication of the Caldwell/Hutchison disputes can be found.

According to Bernstein's interpretation of the growth of knowledge debates, scientific explanation necessarily involves not only a "predictive" dimension but also what has been called a hermeneutical or "interpretive" one. Not only must a theory predict accurately, it must also interpret intelligibly, that is, it must tell a plausible story about how the results explain some otherwise problematic aspect of reality. While an appropriate vehicle of expression for prediction is formal mathematics, the only appropriate medium for the expression of interpretation is the full language of a culture.

Previous to the growth of knowledge literature, philosophers of science tended to believe that science is nothing but measurement and quantitative prediction and that theories are always and only tentative hypotheses with which objective, unambiguous "facts" are confronted. The growth of knowledge theories of science, as Patrick

\footnotetext{
${ }^{7}$ For the purpose of this paper, I will include under the rubric of hermeneutics not only the specific German tradition directly tracing from Schleiermacher, Dilthey, and Weber $(1949 ; 1980)$ but also several other writers whose work has been closely related to that tradition, including parts of the phenomenology and existentialist movements, and especially those whose work traces to Vico, Croce, Bergson, Husserl (1962), Dewey (1929), Collingwood, or the later Wittgenstein (1958). See Austin (1962), Barrett (1979), Berlin (1969), Bernstein (1983), Bleicher (1980), Gadamer (1975a; 1975b; 1976; 1982), Geertz (1973), Gier (1981), Gurwitsch (1974), Heelan (1983a; 1983b), Hirsch (1967), Howard (1982), Ihde (1971), Lauer (1965), Levy (1981), Linge (1976), Luckmann (1978; 1981), Merleau-Ponty (1962; 1964), Natanson (1973), Polanyi (1958b), Polkinghorne (1983), Rabinow and Sullivan (1979), Randall (1984), Ricoeur (1965; 1981), Rorty (1979), Sayer (1984), Schutz (1970), Schutz and Luckmann (1973), Simmel (1980), Strickland (1981), Taylor (1964; 1971; 1980), and Zaner (1974).

${ }^{8} \mathrm{I}$ am of course aware that these terms objectivism and subjectivism have very different meanings in economics from their meaning in philosophy. Even so, there is in the objective theory of value a striving for quantitative measurement and objective laws of historical evolution that is laudably absent from Menger's subjective value theory.
} 
Heelan (1983a, p. 197) put it, "introduce a hermeneutic dimension into natural science." Today, philosophers and historians of science widely agree that the "objectivist" image of the natural sciences is both undescriptive of the actual methods of scientists and internally incoherent as a feasible way of advancing knowledge. In particular, it fails to leave room for an interpretive dimension in which the qualitative plausibility of an explanation can be judged on a par with its quantitative accuracy. ${ }^{9}$

The goal of this paper, then, is to reconstruct an interpretation of economic methodology that is capable of answering the lines of criticism of the Austrians represented by both the Hutchison and Caldwell books, on the basis of the methodological approach elaborated by the Bernstein book. Like all three, my point of departure will be a methodological lesson drawn from the growth of knowledge literature. The next section will summarize the central message of that literature, along the lines elaborated by Bernstein, as a demonstration of the indispensability of the interpretive dimension of all the sciences, as well as the implication of this fact for the problem of theory choice raised by Caldwell against Austrian methodology. Part 3 will then describe some of the main themes of the hermeneutics tradition and the answer it implicitly contains to the problem, raised by Hutchison against the Austrians, of uncriticizable introspective knowledge. Part 4 will then outline a case, based on Mises's methodological writings, that the Austrians' approach represents an application to economics of the insights into human understanding that have been supplied by both the growth of knowledge and hermeneutics literatures.

\section{Science and the problem of theory choice}

What I as a physicist had to discover for myself, most historians learn by example in the course of professional training. Consciously or not, they are all practitioners of the hermeneutic method. In my case, however, the discovery of hermeneutics did more than make history seem consequential. Its most immediate and decisive effect was instead on my view of science.

Thomas S. Kuhn (1977, p. xiii)

Bruce Caldwell's Beyond Positivism outlines a way that supporters of Austrian economics could meet the standards of contemporary methodology if they are willing to confront the problem of theory choice. It may, Hutchison's protestations to

\footnotetext{
${ }^{9}$ Mises, although he may be said to have exaggerated the differences between the human and natural sciences, argued for the need for all sciences to extend in their interpretive dimensions. He criticized his fellow economists for failing to do as well as physicists in this regard. Some economists "do not bother about the meaning of their reasoning and about its reference to the world of real life and action," to which he responds,
}

$[\mathrm{N}] \mathrm{o}$ physicist ever believed that the clarification of some of the assumptions and conditions of physical theorems is outside the scope of physical research. The main question that economics is bound to answer is what the relation of its statements is to the reality of human action whose mental grasp is the objective of economic studies (1966, p. 6). 
the contrary notwithstanding, be completely legitimate to construct deductive systems of economics from a priori true principles. But those who do so ought to either tell us why all the other such systems we could dream up are less useful than the Austrians' own praxeology, or articulate conditions under which a priori systems can be made commensurable. How does the a priori praxeologist answer the challenge of, say, the a priori Marxian? ${ }^{10}$ Caldwell (1982, p. 133) puts the issue to the Austrians concisely:

Their choices, it seems, are twofold. They could attempt to criticize, and hopefully discredit, all rival systems. Such a task would not only be time consuming, it would be literally never-ending. The second alternative, and one that appears more reasonable, is to propose certain criteria which could be used to critically evaluate their own and other such systems.

But this way of putting the problem of theory choice is misleading. In this form, Caldwell's two choices appear to represent a false alternative between what Bernstein calls, respectively, relativism and objectivism. While Caldwell is right that Austrians need to more directly confront the issue of theory choice, the answer to this issue should transcend these equally undesirable alternatives.

Bernstein describes the central message of the growth of knowledge literature not as a skepticist weakening of the once firm criteria of science, as some have viewed it, but rather as an epistemological liberation from objectivism and relativism. It "opens the way to a more historically situated, non-algorithmic, flexible understanding of human rationality, one which highlights the tacit dimension of human judgment and imagination and is sensitive to the unsuspected contingencies and genuine novelties encountered in particular situations" (Bernstein 1983, p. xi). Philosophy of science, he shows, is starting to find its way between the alternative methodological hazards of "objectivism" and "relativism."

By "objectivism" I mean the basic conviction that there is or must be some permanent, ahistorical matrix or framework to which we can ultimately appeal in determining the nature of rationality, knowledge, truth, reality, goodness, or rightness.... The objectivist maintains that unless we can ground philosophy, knowledge or language in a rigorous manner we cannot avoid radical skepticism.

In its strongest form, relativism is the basic conviction that when we turn to the examination of those concepts that philosophers have taken to be the most fundamental...all such concepts must be understood as relative to a specific conceptual scheme, theoretical framework, paradigm, form of life, society or culture. Since the relativist believes that there is (or can be) a nonreducible plurality of such conceptual schemes, he or she challenges the claim that these concepts can have a determinate and univocal significance (Bernstein 1983, p. 8).

\footnotetext{
${ }^{10}$ Both Hutchison (1981, pp. 294-295) and Caldwell (1982, p. 131) cite the Hollis and Nell book (1975) as posing a dilemma for Austrian apriorism. Hollis and Nell propose an apriorism which postulates a very different axiomatic foundation for a deductive science of economics based on Marx's notion of economic reproduction. I made a brief attempt to answer Hollis and Nell in Lavoie (1977), but I now believe that a satisfactory answer requires the sort of reinterpretation of Mises's apriorism that is presented here.
} 
In a sense, objectivism aspires to rid reasoning of all ambiguities, to rid researchers of all biases, to rid scientific disciplines of alternative schools or perspectives. Relativism, on the other hand, wants to abandon the search for a single truth, and hence considers disciplinary rivalries to be ultimately pointless. While objectivism presumes that the problem of theory choice is solvable algorithmically, relativism presumes the problem is inherently unsolvable. Philosophy is now coming to a third position, that the problem of theory choice is non-algorithmically solvable through a certain kind of social process in the scientific community. As Kuhn (1976, pp. 190-191) once put it, alternative paradigms are incommensurable but are not incomparable. "What is lacking is not comparability but a unit of length in terms of which both can be measured directly and exactly."

Some contributors to the growth of knowledge literature may be read as treading dangerously close to one or the other of these hazards, ranging from Popper and Lakatos toward the objectivist end and Feyerabend on the other end. Indeed, it was a characteristic feature of these debates that each writer would repeatedly accuse those on either side of him of objectivistic or relativistic sins. Thus, Lakatos finds Popper too objectivistic and Kuhn, Polanyi, and Feyerabend too relativistic, and so forth. But with the advantage of hindsight we can see beyond the internal differences among these writers, which from within the controversy had appeared so significant, and can discern a much greater measure of congruence among them. The upshot of the debates can be seen as the emergence of a whole new outlook on the nature and philosophical "foundations" of science, an outlook that reveals that we have been permitting objectivistic methodological rules to intrude upon and distort the natural evolution of scientific progress. Although philosophers of science were terrified that any questioning of strict objectivist criteria of science would open the door to rampant relativism and the death of science, Bernstein shows that in fact this fear has been exaggerated - he calls it the Cartesian anxiety - and that there is a way to build a non-objectivistic defense of scientific knowledge. This new defense locates the determining rationality of the growth of knowledge not in any explicit rules known by any single mind, but in the partly tacit judgments of, and the processes of interaction among, the members of the scientific community. The individual member of this community, whether a practicing scientist or philosopher or historian of science, cannot possibly articulate a set of criteria for measuring one theory's advantages over another. The way this process works is by the contention among rival theories for first the attention, then the respect, and ultimately the support of most members of the community of scientists. The reasons scientists are swayed by one rival more than another are never listable in advance but emerge in the process of "interaction itself." 11

One implication of this view of knowledge is that the problem of theory choice, at its roots, is always a matter of whatever happens to persuade open-minded but critical members of the scientific community. There is, as Imre Lakatos has shown, no successful theory of "instant rationality." Intra-paradigmatic standards may be

\footnotetext{
${ }^{11}$ We can see here the aspects of the interpretive dimension of explanation that I termed the tacit and sociological aspects. Among the growth of knowledge writers, the works of Kuhn $(1970 ; 1977)$ and Polanyi (1958a; 1969) have elaborated at length on these aspects. See also Barnes (1982) and Lavoie (1985a; 1985b).
} 
made explicit and this may aid scientific progress, but the only reason we can sometimes rely on such explicit criteria is that they are continually under challenge from rival standards. Scientific progress, as Paul Feyerabend has delighted in showing, depends as much on the violation of scientific standards as on their obedience. Underneath any explicit methodological rule, if it is to help science, there is always to be found a scientist making his own personal judgment either directly about some theory of the way the world works, or indirectly about the standards (or the standards for selecting standards...) to be used in choosing theories. Thus, as Michael Polanyi has shown, we have no choice but to accredit the scientist's tacit powers of judgment, to trust his intuitive sense of what constitutes a worthy contribution to the "Republic of Science." Such refined intuition is what decides which potential contributions "deserve" an allocation of scarce scholarly resources (journal article pages, conference panels, department office space), and which ones do not.

But to say that the scientist's trained intuition is what ultimately guides his or her search for truth is not to say "Anything Goes." Rejecting objectivism does not entail embracing relativism. While alternative paradigms cannot be objectivistically translated into a neutral language and measured against a common set of standards, this does not mean that rivals should give up their vain search for one truth and all go their own relativistic way. On the contrary, our only path to truth lies in their engaging in the process of contention. It is out of the confrontation between two incommensurable theories, their mutual attempts to re-interpret and criticize one another, that we can hope to construct effective comparisons between them. Where we cannot disprove our opponent's theory by finding clear-cut cases of falsification of its predictions, we can still try to persuade him that our interpretation is more compelling than his.

The main thrust of the growth of knowledge debates can be seen as what Bernstein (1983, p. 30) calls a "recovery of the hermeneutical dimension of science":

In the critique of naive and even of sophisticated forms of logical positivism and empiricism; in the questioning of the claims of the primacy of the hypothetical-deductive model of explanation; in the questioning of the sharp dichotomy that has been made between observation and theory (or observational and theoretical language); in the insistence on the underdetermination of theory by fact; and in the exploration of the ways in which all description and observation are theory-impregnated, we find claims and arguments that are consonant with those that have been at the very heart of hermeneutics... (Bernstein 1983, p. 31).

Thus, it might be said that there are two necessary dimensions to all scientific explanation, varying in importance with each particular problem. Along the predictive dimension of any particular scientific explanation, the decisive criterion of success for a (questioned) theory is to be falsifiable but so far unfalsified against the (unquestioned) facts. Here what counts is the degree to which a theory is willing to hazard falsifiable predictions and still survive its confrontation with the facts. But to represent a meaningful contribution to science, any explanation must also extend into the interpretive dimension. Here, it might be said, is raised the question of the "testing" of the (questioned) facts against the (unquestioned) theory. Facts are 
theory-laden. Some prior perspective, an interpretive framework of some kind, must be used to try to "make sense" of any alleged fact, and to determine its significance. Furthermore, any given data set of past facts will be consistent with an infinite number of theories which try to cover an unbounded variety of conflicting predictions of the future. To the extent that predictive accuracy against the facts is insufficient to decide in any particular case between two rival theories, the problem of theory choice becomes one of weighing the plausibility of the interpretive frameworks as devices for making the facts intelligible.

That the predictive dimension of explanation is a necessary one is certainly wellrecognized among economists, thanks in good measure to the multidisciplinary influence of Karl Popper's work. A theory that prohibits nothing, a perfectly flexible interpretive framework with which any imaginable contingency could be made consistent, may be considered a branch of pure mathematics or art, but it represents no contribution to empirical science. A theory must not only be consistent with "the facts," that is, unfalsified so far, but also must be falsifiable, as Popper's early work stressed; an empirical science must make "predictions" of some kind. But this Popperian insight has been substantively qualified in the course of Popper's own writings and throughout the growth of knowledge debates. It is, in the history of science, hard to find any instances of clear falsification. The predictions may properly be very general, hedged, or even unfalsifiable in practice. And the degree of a theory's falsifiability is neither measurable nor suitable as the primary criterion of theory choice. But of course despite all the clarifications since the Logic of Scientific Discovery was first written, the core of truth remains that an explanation which cannot prohibit anything cannot really explain anything.

This by no means implies, however, that falsifiability is the most important consideration in deciding whether or not any purported explanation of real world processes should be taken seriously. A predictive model, no matter how accurate in the past, if it completely lacks interpretive plausibility, is as useless as a compelling interpretive framework that is either unfalsifiable in principle, or has already been clearly falsified. The so-called "fringe sciences" from astrology to parapsychology to creationism, remain outside of the scientific community as much because they are grossly unintuitive to the trained mind of the contemporary scientist, as because of any particular violation they may have made of definite methodological rules, Popperian or otherwise. ${ }^{12}$ Only a miniscule fraction of all the specific claims of "paranormal" phenomena is ever even looked at by "serious scientists," much less scrutinized with the kind of intellectual rigor we associate with the halls of science. The fringe scientists are not typically proven wrong, they are dismissed and ignored. No doubt, readers of the National Enquirer, etc., delight in this, which they see as evidence of scientific dogmatism.

Some methodologists of science have set a trap for themselves by righteously insisting that all challenges to accepted science must be met with careful consideration, as if there were no scarcity of scientific resources. Those such as Kuhn or Polanyi who suggest that some challenges are and should be deemed unworthy of serious examination by the scientific community have been branded

\footnotetext{
$\overline{12}$ A small monthly journal called The Skeptical Inquirer is one of the few places where some of the specific claims of fringe science are addressed by genuine scientists.
} 
"elitists." But clearly scientists have a choice to let their attention be directed by a small arbitrarily selected subset of any and all challengers or to be preselective in directing their attention to the challenges which, on their face, seem pertinent to the current stage of evolution of the scientists' dialogue. Without such a prescreening of "the unintuitive," science would quite simply be at the mercy of kooks.

Scientists by and large decline to pay much attention to purported evidence of, say, the influence of the stars on human affairs, for the perfectly legitimate reason that this strikes their trained intuition as a fruitless avenue of research. They have better things to do with their valuable time. The ongoing process of apprenticeship by which a scientist enters his professional community imbues in him a keen sense of what questions urgently need to be asked, and astrological ones are no longer among them. If it were not for the distressing popularity of such ideas in the lay public, scientists would virtually ignore them altogether. Even when scientists limit themselves to the questions that seem productive to them, blind alleys are frequent enough. Were it to be deprived of the prescreening of "the unintuitive," science would be forever wandering in blind alleys. Scientists have no choice but to trust what could be called their "ability to see what is questionable."13

What scientists in any particular time and place find to be the appropriate problems to pay attention to is shaped as Bernstein says, "dialogically," by the historical tradition of debates from which the current topics in the "conversations" of the sciences evolved. Science is not an unguided accumulation of brute data but a directed orientation to the world by which relevant facts are sought after in order to address problems that are themselves products of the ongoing dialogue of the scientists. ${ }^{14}$ Far from being an invitation to anarchic relativism, the true lesson of the modern debates in methodology is that science will be strengthened by learning to responsibly rely on the skillful judgments of and dialogical contention among its participants. Extending the interpretive dimension of science, properly understood, will not open its gates to the barbarians. Indeed, it may be precisely because philosophers have been attempting and failing to secure those gates with explicit logical criteria of science that the so-called barbarians are threatening them in the first place.

But the role in the growth of knowledge of the scientist's trained intuition is by no means limited to guarding the fringes. Every significant decision a scholar makes in his research is guided by his skillful judgment of relevance, from the most preliminary grasping of a problem, to the resolution to settle on a "solution" as sufficiently plausible to justify moving on to other questions.

The hermeneutical or interpretive dimension of science was minimized by objectivist methodologies in economics and other human sciences precisely because this aspect of explanation was thought to suffer from a basic defect to which the predictive dimension was not subject: the problem of theory choice. If theories are

\footnotetext{
13 The quoted words are those of Hans-Georg Gadamer whose strand of hermeneutics will be examined in part 3. Gadamer points out that it is imagination that is the "decisive function of the scholar. Imagination naturally has a hermeneutical function and serves the sense for what is questionable. It serves the ability to expose real, productive questions..." (1976, p. 12).

14 This orientation to the ongoing conversations of the scientific community is what I termed a "dialogical" aspect of the interpretive dimension. See Hattiangadi (1983, p. 109) for a similar argument.
} 
not arbitrary hypotheses to be tested by confrontation with facts but rather, as Mary Hesse (1980, p. 172) put it, "are the way facts themselves are seen," then the issue arises (to use Michael Polanyi's metaphor), how do you decide through which pair of theoretical spectacles you should try to see the world? How does one decide among alternative theoretical frameworks if simple accuracy in the prediction of facts cannot algorithmically decide the matter? Restricting science to its predictive dimension, where only precision counts, was seen as a way to make theory choice objectively solvable. The growth of knowledge literature has now shown that this objectivist approach only evades but cannot solve the problem of theory choice.

Indeed, in a sense nobody can solve the problem of theory choice if what is demanded is a list of specific criteria that will once and for all distinguish truth from falsehood. It is irrational, however, to impose such criteria of "rationality" upon the process of scientific criticism. In fact, the problem of theory choice can be solved and is solved every day in the only way the human mind can solve problems: by trying to look at the world through alternative pairs of spectacles until one is convinced, for now, that one is "seeing" clearly. Or as Fritz Machlup used to say, we have no choice but to rely on the "ahahness" criterion. We know a good explanation when we see one, and when it induces us to say ahah. ${ }^{15}$ Bernstein calls it a "dominant theme" of the growth of knowledge literature that

theory-choice is a judgmental activity requiring imagination, interpretation, the weighing of alternatives, and application of criteria that are essentially open. But such judgments also need to be supported by reasons (reasons which themselves change and vary in the course of scientific development). It is not a deficiency but an intrinsic characteristic of this judgmental process that rational individuals can and do disagree without either of them being guilty of making a mistake. While the "balance of argument and counter-argument" in support of conflicting judgments "can sometimes be very close indeed," in the course of further scientific development the force of the arguments in support of one of these conflicting judgments does become decisive for the community of relevant scientists. ${ }^{16}$

The critical process in the scientific community does involve criteria for weighing interpretive frameworks but these operate as modifiable maxims guiding tacit judgments rather than as specific, objective, and certain rules of theory choice. And this process is indeed a never-ending one although its inconclusiveness need not imply a retreat to relativism. Caldwell's problem of theory choice needs to be answered by Misesians but it equally needs to be addressed by all economists, and indeed by all social and natural scientists. In no case is there an easy or conclusive resolution. Theory choice inevitably rests on the judgments of scientists about those interpretive frameworks from within which they believe they can best see the world.

Richard Rorty (1979) may have been the contemporary philosopher who most clearly identified the problem that has plagued our objectivistic methodological reasoning. The aspiration of what Rorty calls "foundationalism" in its many forms is

\footnotetext{
${ }^{15}$ For a useful discussion of Machlup's methodology which shows his affinity with Schutz, see Langlois and Koppl (1984).

${ }^{16}$ Bernstein (1983, pp. 56-57). The words Bernstein quotes here are Kuhn's (1970, p. 157).
} 
to place all knowledge on a firm methodological foundation which can thereby render it immune from future criticism. Modern economics seems to be under the powerful sway of two varieties of foundationalism which could be called Euclidean and falsificationist. Euclidean foundationalism hopes to "found" our knowledge by fitting it into an axiomatic, deductive framework along the lines of general equilibrium theory and game theory (and some would say Misesian apriorism). Falsificationist foundationalism, on the other hand, strives to secure our knowledge from criticism by insisting that we formulate all our explanations in the form of hypotheses which can be falsified in statistical tests. Both varieties of foundationalism have been essentially trying to supply an algorithm for theory choice, one by making our reasoning rigidly deductive on the model of axiomatized mathematics, the other by making our reasoning rigidly inductive on the model of the experimental natural sciences. Contrary to both, the growth of knowledge literature teaches us that scientific theories are neither strictly deductive and, thus, dichotomized from history nor strictly hypothetical and generated by induction from history, but can be better described as alternative devices for interpreting the historical world. The choice among such interpretive theories is not algorithmically solvable by any foundationalist procedure but depends upon the tacit judgments and interactive processes taking place in the community of scientists.

\section{Hermeneutics and "knowledge from within"}

Believing, with Max Weber, that man is an animal suspended in webs of significance he himself has spun, I take culture to be those webs, and the analysis of it to be therefore not an experimental science in search of law but an interpretive one in search of meaning. It is explication I am after, construing social expressions on their surface enigmatical.

Clifford Geertz (1973, p. 5)

The main thrust of T.W. Hutchison's critique of praxeology is his contention that, since it relies on "introspection," it can never constitute an addition to science but only an assertion of personal belief. His challenge is that Austrian methodology fails to meet the standards of science as represented by the growth of knowledge literature. Against this view, the present section will argue that the source of knowledge Hutchison (1981, pp. 282-283) derides as "introspective certainties given by inner observation" should not be so casually dismissed. There is a notion, common to the hermeneutics and Austrian methodological traditions, of a kind of knowledge that is called "from within" but which is neither exclusively private nor beyond interpersonal criticism. Since, as the previous section has argued, the central theme of the growth of knowledge literature was the introduction of an interpretive dimension into scientific explanation, Hutchison's challenge can be turned against him. It may not be Mises who violated the spirit of the growth of knowledge literature by opening science to "knowledge from within" but rather Hutchison who does so by closing it.

The purpose of this section is to present the hermeneutical perspective as one that is fully consistent with the growth of knowledge literature's view of scientific 
explanation, but as an important extension of that work into the specific domain of the social or human sciences. The data set from which the growth of knowledge theories of science was formulated was, after all, confined almost entirely to the natural sciences. For the most part, the growth of knowledge writers seems to have taken methodological monism for granted, as had their objectivist predecessors. As more than one economist has pointed out, "the lack of social science case studies as inputs into this philosophical debate leaves us unsure about what exactly we can learn from it." 17 But if Richard Bernstein and others are correct in identifying the essential lesson of the growth of knowledge approach as a hermeneutic one, then economics and social sciences in general constitute better, not worse, data sets for the approach. The interpretive dimension of explanation takes on even greater significance in the social sciences than it does in the sciences examined in the growth of knowledge literature.

Hermeneutics first entered methodological debates with Wilhelm Dilthey's contributions in the late nineteenth century on the side of strict methodological dualism. Like most Austrian economists they left "objectivism" to the natural sciences and promoted interpretation as a method that was thought to be specific to the human sciences alone and not at all to the natural sciences. Dilthey formulated the method of verstehen, understanding the subjective meaning of things and events to individual human beings, as the unique dimension of the historical sciences. Before Dilthey, traditional hermeneutics was developed from the practice of textual interpretation, both of Biblical and legal texts, culminating in the work of Schleiermacher. But with Dilthey and then Max Weber, hermeneutics began to aspire to being a scientific methodology on a par with the methodology of the natural sciences. The chief weakness of Dilthey's contribution to the theory of interpretation was its separation of interpretation from causal explanation. Explaining cause and effect was to be the task of the natural sciences, understanding purposes was to be the task of the social sciences. Strict methodological dualism thus seems to strip the human sciences away from the empirical sciences. The focus of post-Diltheyan hermeneutics has been on reconnecting explanation and interpretation. The human sciences are also empirical; they too, like the natural sciences, must extend in the predictive dimension, must deny some imaginable states of affairs. Unlike the natural sciences, however, the human sciences study the world of everyday experience, the "life-world." This world is, as Richard M. Zaner (1974, p. 392) wrote, "peopled with others and their 'products' (cultural objects, institutions, mores, values, recipes for acting, laws, and the like); 'things' in the world are not for our daily lives simply 'physical,' but are sedimented with 'meanings,' 'purposes,' and 'values' (norms, goals, histories, uses, and the rest)."

In the debates over the methods proper to the human sciences that have taken place in the hermeneutics literature can be discerned the very same attempts to transcend the twin dangers of relativism and objectivism that can be found in the growth of knowledge literature. One important strand of hermeneutics, running from Dilthey to Emilio Betti to E.D. Hirsch, has endeavored to objectify or codify some of

\footnotetext{
${ }^{17}$ Axel Leijonhufvud (1981, p. 291). Leijonhufvud offered several reasons why he thinks economists in particular should be hesitant to apply this natural-science-oriented view of methodology to the very different case studies to be found in economics.
} 
the central lessons that have been gathered over the years from the practice of textual interpretation. This point of view criticizes traditional hermeneutics for being too relativistic. Another strand, running from Dilthey to Martin Heidegger to HansGeorg Gadamer, on the other hand, criticizes traditional hermeneutics for being too objectivistic. In a manner that reminds one of Kuhn's or Feyerabend's critiques of the objective methodological rules of Popper or Lakatos, Gadamer criticizes the "hermeneutical canons" of Betti. And in a manner reminiscent of the critiques by Lakatos and Popper of Feyerabend's alleged relativism, we can find Betti suspecting Gadamer of "open[ing] the door to subjective arbitrariness."18

But again, a closer look reveals a greater underlying consensus within this literature than its participants themselves usually acknowledge. The canons of Betti and Hirsch are not quite the clear-cut methodological devices for revealing the "one true interpretation" that their proponents sometimes suggest, any more than Popper's and Lakatos's rules are the sort of devices that their proponents wanted for clearly demarcating science from dogma. But in both cases, as Gadamer and Kuhn have shown, the canons or rules are not to be rejected as worthless. Instead they are to be redefined as maxims or rules-of-thumb whose application depends on the partly tacit skills of the members of the scientific community. They are learned in the process of apprenticeship of the prospective scientist and applied skillfully by practitioners of scientific methods. These maxims do not remove the need for the individual scientist to take personal responsibility for his ability to make informed judgments. They do not make the problem of theory choice algorithmic.

While from a modern point of view some contributors to hermeneutics can be charged with having granted objectivism too much by presuming it appropriate for the natural sciences, they had reasons to stress the differences between what might be called the more predictive natural sciences and the more interpretive human ones. In the natural sciences we do not literally interpret the "actions" of the objects of our research, as if they had intentions of their own (although we may often do so metaphorically). Interpretation enters on the level of perception (both directly observing the phenomena under examination and indirectly in the reading of scientific instruments) and on the level of the understanding of other scientists' explanations. Modern science understands that we should not view natural events as if they were meaningful actions of, or messages from, some supernatural being. The social sciences, on the other hand, are about already interpreted meanings. The natural sciences are interpretations of external things, or as the Weberian sociologist Alfred Schutz put it, "constructs of the first degree" while the social sciences are interpretations of interpretations, or "constructs of the second degree."19

We see natural phenomena, as it were, "from the outside," and so we are forced to invent possible models to explain their regularities. It is true that our inventions, even here, are never really $a b$ novo but arise from metaphors relating to the lifeworld. Of natural objects themselves, however, we immediately know very little. We postulate possible "meanings" and impute them to natural phenomena metaphorically and hypothetically. We treat nature as if it confirmed to "purposes" embodied

\footnotetext{
${ }^{18}$ See Bleicher (1980, p. 83).

${ }^{19}$ Schutz (1970, p. 273). See also Gurwitsch (1974, p. 129).
} 
in laws. As Dilthey (1976, p. 248) said, "Understanding of nature-interpretatio naturae-is a figurative expression."

By contrast, when we study human societies the purposes we attribute to the objects of our examination are not metaphorical but real and already meaningful to them. We are able to view them "from the inside." Richard Zaner (1974, p. 392) noted that "the social world is experienced as already constituted and meaningful by each of us in our daily lives." Or as Gadamer (1976, p. 15) said, "There is always a world already interpreted, already organized in its basic relations, into which experience steps." The task of the social scientist is to find and explicate a meaning that is always already there, rather than to invent a merely metaphorical "meaning" which works in predictive tests.

The question arises, however, why couldn't we use the successful procedure of the natural sciences to see human phenomena as objective "behavior," viewing them from the outside, as well? Why must we care about any subjective meaning which the objects of our study may have about their actions? Alfred Schutz probably posed this challenge to hermeneutics better than its critics have:

Why not honestly describe in honestly objective terms what really happens, and that means speaking our own language, the language of qualified and scientifically trained observers of the social world? And if it be objected that these terms are but artificial conventions created by our "will and pleasure," and that therefore we cannot utilize them for real insight into the meaning which social acts have for those who act, but only for our interpretation, we could answer that it is precisely this building up of a system of conventions and an honest description of the world which is and is alone the task of scientific thought; that we scientists are no less sovereign in our system of interpretation than the actor is free in setting up his system of goals and plans; that we social scientists in particular have but to follow the pattern of natural sciences, which have performed with the very methods we should abandon the most wonderful work of all time (1970, p. 265).

The problem with this behavioralistic point of view is that those who claim to hold to it do not in fact take it seriously. In their own scientific activities they proceed on the basis of a naive acceptance of the life-world. As Schutz pointed out, "radical behaviorism stands and falls with the basic assumption that there is no possibility of proving the fact that "the fellowman" is intelligent which behaviorism therefore regards as a "weak fact" not capable of empirical testing. Schutz turns this view against itself, when he remarks,

Yet, it is not then quite understandable why an intelligent individual should write books for others or even meet others in congresses where it is reciprocally proved that the intelligence of the other is a questionable fact. It is even less understandable that the same authors who are convinced that no verification is possible for the intelligence of other human beings have such confidence in the principle of verifiability itself, which can be realized only through cooperation with others by mutual control (1970, p. 266).

As shown also in the growth of knowledge literature, the abandonment of objectivism does not have to entail embracing relativism. Schutz (1970, p. 265), for 
example, calls it "the essence" of science to be "objective" in the sense of "valid not only for me, or for me and you and a few others, but for everyone" and states his anti-relativism unequivocally: "scientific propositions do not refer to my private world but to the one and unitary life-world common to us all." Similar views can be found throughout the hermeneutics literature and often in similar words to those used against relativism in the growth of knowledge debates. And once again, the direction toward which these ideas point is not an undermining of all knowledge but an acceptance of its ultimate dependence on an unarticulated sociological process by which scientists and their interpretations interact. The "foundation" of scientific explanation is not a matter of any philosopher's explicit criteria of science but is rather to be discovered in the commonsense linguistic understanding into which each of us has been enculturated, that is to say, in the "life-world."

To some extent natural sciences can, as it were, get away with implicitly taking the life-world and the intelligence of other minds for granted, while explicitly disavowing any belief in them. But the human sciences cannot afford to misrepresent what is their primary object of investigation. One of Schutz's followers, Aron Gurwitsch (1974, p. 24), concisely stated the special problem that faces the social scientist in these terms:

Given a certain cultural world as the life-world of a sociohistorical group, the task is to find and to lay bare the acts of consciousness which in their systematic concatenation and intertexture make this specific world possible as their correlate. Answering this question for a particular cultural world amounts to understanding that world from within by referring it to the mental life in which it originates.

One of the important contributions of the hermeneutics tradition has been its demonstration that social scientists cannot pay exclusive attention to "what this world means to them" if they wish to provide a satisfactory explanation of human history. They must rather direct their attention to "subjective meaning," to the "specific meaning and relevance structure for the human beings living, acting and thinking therein." ${ }^{20}$ The interpretive sociology of these writers bears a striking similarity to the tradition of methodological individualism in post-1870 microeconomics. For Max Weber, the principles of choice under scarcity are a central concern of the interpretive human sciences. He held that "All serious reflection about the ultimate elements of meaningful human conduct is oriented primarily in terms of the categories 'ends' and 'means"' (1949, p. 52), and like Robbins, defined the subject matter of economics on the basis of choice under scarcity:

Most roughly expressed, the basic element in all those phenomena which we call, in the widest sense, "social-economic" is constituted by the fact that our physical existence and the satisfaction of our most ideal needs are everywhere confronted with the quantitative limits and the qualitative inadequacy of the necessary external means, so that their satisfaction requires planful provision and work, struggle with nature and the association of human beings (1949, pp. 63-64).

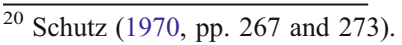


The method, if it can be called that, which these writers proposed for the social scientist is not fundamentally different from the method by which we understand our fellow man in everyday life, but is simply intended to represent a more careful and systematic effort. Schutz (1970, p. 273) uses the example of deciding whether a defendant has shown "premeditated malice" or "intent" in killing a person, in order to suggest that, again, practically speaking we all trust our ability to understand one another's meaning. The social scientist, Schutz has shown, must not only trust, as must the successful natural scientist, but also rely primarily on this verstehen or understanding in his effort to construe history as an intelligible sequence of meaningful events.

Unfortunately, Dilthey and others sometimes described the method of verstehen as a kind of mystical appropriation of the object's point of view by empathy. This view of understanding as psychological empathy has been rejected by most modern contributors to the hermeneutics tradition such as Schutz, Gadamer, Paul Ricoeur, and Clifford Geertz. As Geertz describes this point, one can easily see parallels with the attempts to go beyond objectivism and relativism in the growth of knowledge literature: He suggests we should try to "produce an interpretation of the way a people live which is neither imprisoned within their mental horizons, an ethnography of witchcraft as written by a witch, nor systematically deaf to the distinctive tonalities of witchcraft as written by a geometer?" (1979, p. 227). We can neither ignore our object's point of view, nor escape our own and adopt his.

The work of Hans-Georg Gadamer has clarified the "other side" of the event of interpretation, the observation that the historian cannot try to pay exclusive attention to "what this world means to the actors in it" if they wish to provide a satisfactory explanation of human history. We cannot jump out of our cultural skins and into those of the objects of our investigations. Contrary to many of the statements of Dilthey, Weber, Schutz, Betti, and Hirsch, it would be cognitively disastrous to take seriously the role of a "detached" scientist, to try to cut oneself off from one's own cultural/historical background, or try to really see things "as the actors themselves must have been seeing them." Good history cannot be perspectiveless any more than good science can be. The earlier writers in hermeneutics tended to take historical and cultural distance to be strictly problems to be overcome, whereas Gadamer points out that they can also be the source of profound insight. The interpreter should not try to rid himself of his own perspective in order to "adopt" that of the interpreted but must try to find new ways to use his presuppositions to attain a better understanding of the human activities under study. While he can never leap into another's skin, he can try to expand his own horizon to overlap that of the other, as Gadamer puts it, by engaging in a sort of dialogue with the other perspective. ${ }^{21}$

Hermeneutics, as David Linge (1976, p. xii) phrased it, "has its origin in breaches in intersubjectivity." The tradition began with the problem of correcting failures in the interpersonal transmission of meaning within the life-world. Difficult texts written from foreign languages or points of view or historical epochs were what required a sustained effort of interpretation. It was from this sort of effort at the explication of incongruous texts that the analytical approach distinctive of this literature emerged: the hermeneutical circle. The subjective meaning of any

$\overline{{ }^{21}}$ This constitutes what was called the "perspectivistic" aspect of the interpretive dimension. 
uninterpreted subset (say, a sentence) of a writer's life work can only be disclosed by reference to the whole (a paragraph, or the whole article, or his life's work) of which it is a part. By the same token, however, the whole is made up entirely of such parts, and, thus, its meaning can only be derived from theirs.

The hermeneutical circle, as Bernstein's book shows, helps us to transcend the false ideal of objectivism without sinking into relativism. One of Dilthey's translators, H.P. Rickman, concisely described Dilthey's conception of the hermeneutical circle:

Put negatively this principle means that there are no absolute starting-points, no self-evident, self-contained certainties on which we can build, because we always find ourselves in the middle of complex situations which we try to disentangle by making, then revising, provisional assumptions. This circularity - or perhaps one might call it a spiral approximation towards greater accuracy and knowledgepervades our whole intellectual life (1976, p. 11).

This "circle" is seen by these writers as a kind of procedure for interpretation that involves, in Clifford Geertz's words, "a continuous dialectical tacking between the most local of local detail and the most global of global structure in such a way as to bring both into view simultaneously" (1979, p. 239). We accept those interpretive frameworks which evoke the most compelling gestalt picture of the whole as constituted by its subsidiary parts and of the parts by reference to their structural relationship to the whole. ${ }^{22}$ More compelling pictures in this sense would be those which most comfortably conform to the individual scientist's presuppositions, themselves the products of a long evolution of scientific dialogue.

It is just such presuppositions of which Gadamer was speaking when he asked that we restore to linguistic usage "a positive concept of prejudice," for which Bernstein (1983, p. 128) coins the term "enabling" as contrasted with blind prejudices:

Prejudices are not necessarily unjustified and erroneous, so that they inevitably distort the truth. In fact, the historicity of our existence entails that prejudices, in the literal sense of the word, constitute the initial directedness of our whole ability to experience (1976, p. 9).

The preoccupation of much of the earlier hermeneutics literature on the resolution of misinterpretation, that is, on interpretation failures rather than successes, has been criticized by Gadamer for disguising the positive or enabling aspects of "prejudice." 23

\footnotetext{
${ }^{22}$ Michael Polanyi's epistemology is constructed upon this Gestalt approach involving the relationship between subsidiary clues and focal awareness.

${ }^{23}$ Dilthey did recognize this point in several passages, for example, when he said of his basic point of view that it "consistently recognizes that it is impossible to go beyond consciousness, to see, as it were, without eyes or to direct a cognitive gaze beyond the eye itself' (1976, p. 161), or when he said:
}

The comprehension of the historical system of interactions grows first of all from individual points at which related remnants of the past are linked in understanding by their relation to experience: what is around us helps us to understand what is distant and past (1976, p. 203).

But in the very next passage, Dilthey seems to imply, contrary to Gadamer, that "what we put into" our interpretations must only be "permanently and universally valid for man," as if all nonuniversal features of the historian's background could be perfectly expunged from his mind. Mises, we will see, did not suffer from this illusion. 
Successful intersubjectivity was sometimes taken for granted as the norm, without tracing it to its enabling conditions, and the procedure for eliminating interpretive error was sometimes carelessly put in terms of a form of objectivism, of striving to discard all the biases inherited from one's own culture. Schutz, for example, refers to the attitude of the social scientist as that of "a mere disinterested observer" who "detaches himself from his biographical situation" (1970, pp. 275-276). Gadamer argues that attempts to achieve this kind of objectivity could only result in making interpretation impossible.

No one disputes the fact that controlling the prejudices of our own present to such an extent that we do not misunderstand the witnesses of the past is a valid aim, but obviously such control does not completely fulfill the task of understanding the past and its transmissions (1976, p. 6).

A hermeneutic approach demands that we recognize history not as a neutral reconstruction of the past purely on the basis of the subjective meanings of its actors, but as a mediation between a present and a past to which that present is, fortuitously, related. Not only is the subjective meaning of the observed an indispensable referent of any adequate social scientific explanation, as Dilthey showed, so is the subjective meaning of the observer whose "prejudices" guide the investigation. For Dilthey, one might say, interpreting an ancient text demands that the interpreter try to go back to its original context, while for Gadamer it demands that the interpreter bring the text and what we know of its context into the present, into the "living presence of conversation, whose fundamental procedure is always question and answer" (1975a, p. 331).

Gadamer thus argues that "understanding the historical significance of an action presupposes that we do not restrict ourselves to the subjective plans, intentions, and dispositions of the agents," and that significance cannot be fully separated from observation. ${ }^{24}$ As R.G. Collingwood (1946, p. 215) put it, "The historian not only re-enacts past thought, he re-enacts it in the context of his own knowledge and therefore, in re-enacting it, criticizes it, forms his own judgment of its value, corrects whatever errors he can discern in it."

Thus "enabling prejudices," elements of shared understandings which are "passed down" to us as traditions, are what make the mutual communication among scientists possible. We only understand our world because we understand one another. We only understand each other, in turn, because we all spent some substantial part of our lives being enculturated into the life-world, a specific domain we have in common. It is in this realm of the intersubjective and the taken-forgranted that our tacit powers of judgment are developed. We are for the most part unaware of the tacit powers, as Michael Polanyi calls them, by which we direct our minds toward the solution of problems we "find" interesting, but they nevertheless are what make rational discourse possible. We cannot, therefore, afford to shut off from ourselves all presuppositions, as is the aim of objectivism, for some of these

\footnotetext{
${ }^{24}$ Gadamer (1976, p. 122), emphasis added. Hirsch (1967) has argued that a sharp distinction can be made between the content of history and its significance, and that the prejudices of the historian can be carefully eliminated from statements of fact but not from statements about the significance of facts.
} 
"prejudices" constitute our common life-world which enables the whole process by which scientific knowledge emerges and grows.

It can be just as important to possess the right presuppositions - to be asking the right questions - as it is to answer them accurately. And if this is the case then every contribution to science should be ready and willing to justify the pertinence of the questions it tries to answer, a matter which can only be addressed qualitatively, and not quantitatively. Gadamer's remarks about statistics underscore the need for the interpretive dimension of even the most quantitative research.

Statistics provides us with a useful example of how the hermeneutical dimension encompasses the entire procedure of science.... [W] hat is established by statistics seems to be a language of facts, but which questions these facts answer and which facts would begin to speak if other questions were asked are hermeneutical questions (1976, p. 11).

Methodological sterility, by which Gadamer means "the application of a method to something not really worth knowing" is the product of failing to recognize the importance of asking the right question. "No assertion is possible," writes Gadamer, "that cannot be understood as an answer to a question, and assertions can only be understood in this way" (1976, p. 11).

Nor can statistics be considered a final arbiter between alternative interpretations, as Max Weber had suggested. The Wittgensteinian philosopher Peter Winch (1958, p. 113) concisely argued against Weber that "if a proffered interpretation is wrong, statistics, though they may suggest that that is so, are not the decisive and ultimate court of appeal for the validity of sociological interpretations" and that "What is . . . needed is a better interpretation, not something different in kind." Theory choice cannot be made algorithmic by trying (as Popper did) to restrict the interpretive dimension to the discovery phase of science, to the formulation of hypotheses which can then be selected by strict quantitative tests. Interpretation, Polanyi (1972) has shown, underlies all phases of science including the validation and testing of hypotheses, and, as Bernstein put it, is not merely of value "in helping to clarify how social scientists make good guesses and invent hypotheses" (1983, p. 27).

It follows from this view of "enabling prejudices" that one of the key aspects of any interpretive explanation must be an emphasis on the historical roots of our present actions and knowledge. History of thought can no longer be seen as an extra specialty for those with a peculiar curiosity about ideas of dead men, but must be seen as an integral part of any scientific discipline. And history proper is in this view not an attempt to find quantitative covering laws that fully determine a sequence of events, but an attempt to supply a qualitative interpretation of some part of mankind's "story." The whole purpose of all of the theoretical social sciences (including economics) is to equip the historian with the capacity to better distinguish acceptable from unacceptable historical narratives. It was Dilthey's aspiration to build an epistemological foundation for the human sciences as a whole, which he divided into "two great classes," that is, "the study of history (including the description of the contemporary state of society) and the systematic human studies" which he says "are, throughout, dependent on each other and form a solid whole" (1976, p. 171).

As Paul Ricoeur has shown, the articulation of human history has an "irreducibly narrative character," and good history shares many of the attributes of good fiction. 
Essentially to impart the subjective meaning and significance of events in history involves us not in a search for determinate laws but in the act of storytelling. ${ }^{25}$

Accordingly, to follow a story is to understand the successive actions, thoughts and feelings as displaying a particular directedness. By this I mean that we are pushed along by the development and that we respond to this thrust with expectations concerning the outcome and culmination of the process. In this sense, the 'conclusion' of the story is the pole of attraction of the whole process. But a narrative conclusion can be neither deduced nor predicted. There is no story unless our attention is held in suspense by a thousand contingencies. Hence we must follow the story to its conclusion. So rather than being predictable, a conclusion must be acceptable. Looking back from the conclusion towards the episodes which led up to it, we must be able to say that this end required those events and that chain of action (1981, p. 277).

What we find ourselves doing in the social sciences is not so much the testing of ex ante predictions but is more of the nature of an ex post explanation of principles. The only "test" any theory can receive is in the form of a qualitative judgment of the plausibility of the sequence of events that has been strung together by narrative. Theoretical sciences like economics can supply the principles of explanation but only the historical narrative can put these principles to work and establish their applicability and significance in some specific concrete circumstances under investigation. ${ }^{26}$ But elevating the role of history and tradition in science does not imply a denigration of reason. On the contrary, these writers charge their critics with having caused an impoverishment of reason by divorcing it from practical reasoning and equating it instead with "a strictly formal scientific methodology" (Rabinow and Sullivan 1979, p. 9). Bernstein points out that if we seek to trace the sources of our

\footnotetext{
${ }^{25}$ In a fascinating review of three recent books (Earl 1983; Ford 1983; Kay 1984) which criticize the treatment of choice by neoclassical economics as a narrow optimizing exercise, the mathematical economist John D. Hey (1984, p. 207) agrees with the points made by the three critics but cannot seem to bring himself to condone their non-formal style. Finding the applied parts of one of the books "frustratingly anecdotal," he wonders "if this is inevitable with a non-optimality (or non-neoclassical...) approach. Once one departs from a well-defined problem area and a well-defined objective function, one seems to drift into storytelling". Viewed from the blinders of objectivistic presuppositions, case studies are mere anecdotes and narrative histories are deemed inferior to tests of "well-defined objective functions". See also Randall (1984).

${ }^{26}$ This represents what was called the "historical" and "narrative" aspects of the interpretive dimension of explanation. Edmund Ions (1977, pp. 152-153), summarizing the views of Giambattista Vico, describes the danger of excluding the historical dimension from the human sciences:
}

In rejecting Descartes' insistence on the deductive method in the Discours, and its concomitant stress on geometric methods for the exploration of rhetoric and poetry, Vico advanced-his own more profound approach to humane studies. The prime postulate was the role of imagination in ordering the past and the present into intelligible forms. For this task, Vico argued, the a priori truths of mathematics are of limited utility. Of much greater importance is a sense of history, created by the historical imagination; a conscious and deliberate attempt to explore the feelings, volitions, insights, intuitions of man's knowledge about himself, then to allow these to play upon the human understanding, in all their contradictions, harmonies and disharmonies. To exclude such reflections by some narrow circumscription of how knowledge arrives... is to impoverish the inquiry. 
prejudices, both those that distort our vision of reality and those that enable it, "then we must turn to the past, to tradition, and to the proper authority (based on knowledge) which 'implants' these prejudices." It is in this sense that Bernstein, following Gadamer, challenges the opposition between reason and tradition:

All reason functions within traditions.... There has been a deformation of the concept of tradition when we think of it as the "dead weight" of the past. A living tradition not only informs and shapes what we are but is always in the process of reconstitution. When tradition is no longer open in this manner, we can speak of it as "dead," or as no longer a tradition (1983, p. 130).

Through the transmission of presuppositions via tradition, each individual mind is able to gain access to, and thereby, himself influence the realm of the intersubjective. It is from this interpersonal confrontation of subjective minds that the progressing body of mutually accepted knowledge we call science emerges.

The most important mechanism by means of which each of us gains access to the intersubjective is the learning of a language. ${ }^{27}$ As Gadamer(1976, p. 87) emphasizes, speaking is more than a deliberate use of "tools" of communicating ideas, as if these were held within the mind independently of its culture and mode of expression. Rather, learning to speak "means acquiring a familiarity and acquaintance with the world itself and how it confronts us" (1976, p. 63).

The language one masters is such that one lives within it, that is, "knows" what one wishes to communicate in no way other than in linguistic form. "Choosing" one's words is an appearance of effect created in communication when speaking is inhibited (1976, p. 87).

That language is an indispensable window through which we comprehend the world is not to say that what we understand of each other's speaking and writing is somehow limited to that which is actually articulated in words. "Language," writes Gadamer (1976, p. 88), "is not coincident, as it were, with that which is expressed in it, with that in it which is formulated in words." As Bernstein shows, this conception of what Gadamer calls "that which is said in spite of not being said" bears great similarity to themes in the growth of knowledge literature, such as Kuhn's discussions of the limits of paradigm translation and Polanyi's notion of inarticulate knowledge.

Thus interpretation always means adding to what is said through a mediation of the "horizons" of the interpreter and the interpreted. What Gadamer says of understanding the meaning of a text is equally true of all attempts to understand the actions or statements of other persons:

The real meaning of a text as it addresses the interpreter does not just depend on the occasional factors which characterize the author and his original public. For it is also always co-determined by the historical situation of the interpreter and thus by the whole of the objective course of history... The meaning of a text surpasses its author not occasionally, but always. Thus understanding is

\footnotetext{
$\overline{27}$ Gadamer (1976, pp. 62-63) observes that "We grow up and become acquainted with men and in the last analysis with ourselves when we learn to speak."
} 
not a reproductive procedure but rather always also a productive one.... It suffices to say that one understands differently when one understands at a11. ${ }^{28}$

The power of language lies primarily in its capacity to mean more than can be explicitly said. It opens the community of its users to "the infinity of the unsaid."29 Those in the economics profession who dismiss linguistic expression for its lack of precision, for the fact that it leaves itself open to more than one interpretation, are simultaneously condemning the source of all the genuinely communicative force of language. Reducing economic discourse to formalism may add in some cases to its clarity, but it also may seriously reduce what the science is able to say. Gadamer notes that "Linguistic expressions, when they are what they can be, are not simply inexact and in need of refinement, but rather, of necessity, they always fall short of what they evoke and communicate." 30

This fact that "we live wholly within a language," does not, for Gadamer (1976, pp. 15-16), constitute a form of "linguistic relativism" because there is "absolutely no captivity within a language," any more than there is, for Kuhn, any rigid captivity within a paradigm. It is precisely through the use of language in scientific dialogue that the growth of knowledge is able to occur. It is from scholarly debate, from the effort to confront alternative interpretations of reality with one another in verbal discourse, that our capacity to understand that reality has expanded, whenever it has.

We have returned, then, to the conclusions of the previous section, that science is more dialogical than logical, more a matter of a back and forth interplay of partly implicit perspectives than a linear accumulation of explicit facts, more a dynamic process among scientists in which meaning unfolds spontaneously, than a static body of data deliberately acquired. All this is as true of the human as it is of the natural sciences. Moreover, an indispensable source of knowledge of the world for all sciences, but of special significance for the human ones, is the understanding we share of the life-world, of the domain of the intersubjective. We are capable, because we are human, of making intelligible the subjective meaning of others, whether the meaning of their actions or their words. It is only this ability that makes any science possible. And in the human sciences, including economics, it is this structure of the intersubjective meanings of individual agents which forms the primary material for our scholarly attention.

\section{Praxeology as an interpretive approach to economics}

We approach the subject matter of the natural sciences from without. The result of our observations is the establishment of functional relations of dependence. The propositions concerning these relationships constitute the general

\footnotetext{
${ }^{28}$ Gadamer (1960, p. 280), as excerpted and translated by Linge (1976, p. xxv).

29 See Gadamer (1960, pp. 443-444). As Linge (1976, pp. xxxii-xxxiii) puts it, "The infinity of the unsaid that is essential to language cannot be reduced to propositions, that is, to the merely present-at-hand, for every new interpretation brings with it a whole new "circle of the unexpressed."

${ }^{30}$ Gadamer (1976, p. 88). This is the aspect of the interpretive dimension that I called "linguistic."
} 
principles by which we explain the phenomena of nature. Once we have constructed the system of these principles, we have done all that we can do. In the sciences of human action, on the other hand, we comprehend phenomena from within. Because we are human beings, we are in a position to grasp the meaning that the actor has attached to his action. It is this comprehension of meaning that enables us to formulate the general principles by means of which we explain the phenomena of action.

Ludwig von Mises (1981, p. 130)

Definite hermeneutical strands can be found throughout the methodological writings of the Austrian school. Several members of the school including Lachmann (1971), Grinder (1977), Ebeling and Richard (1985), O'Driscoll and Rizzo (1985), and Rothbard (1973), have explicitly tied their work to parts of the hermeneutic tradition. There is a striking similarity among the arguments of all of the writers in the Austrian and hermeneutical traditions on the need to interpret human history by reference to the subjective meanings of individuals. The style in which Austrians practice their economics might be said to be exactly what hermeneutics recommends for social science in general. What little applied work this school has engaged in has been done in an extremely disaggregated way, case studies being preferred, and the theoretical apparatus is built in words and for use as an interpretive apparatus for the comprehension of history. Both hermeneutics and Austrian economics espouse consistent subjectivism and methodological individualism and seem intent on paying what others often consider undue stress on the history of ideas, and the interpretation of texts.

It was, according to the Austrians, nothing less than the central message of the marginalist revolution, in which neoclassical economics was born, that value and other economic phenomena are to be explained by reference to the subjective meaning attached to them by individual human minds. It would be impossible to equate the methodological positions of all of the diverse writers in the Austrian tradition. Indeed there can be discerned in the methodological debates of contemporary Austrians the very same struggle between more objectivistic and more relativistic factions as was found in the growth of knowledge and hermeneutics traditions. ${ }^{31}$ Once again we can find an underlying unity within the tradition that suggests a way of transcending these alternative hazards. In fact, the very aspects of the interpretive dimension that I have called the historical, linguistic, narrative, dialogical, perspectivistic, tacit, and sociological aspects could almost serve as well to distinguish the modern Austrians from other branches of neoclassical economics as they can to delineate the themes of hermeneutics.

For example, Friedrich Hayek is not at all difficult to interpret as fully consistent with the growth of knowledge and hermeneutical approaches. A close friend of Karl Popper, Hayek was well aware of and in overall agreement with the growth of knowledge writings, and his method of "explanation of the principle" can be seen as a hermeneutical use of theory as a framework for the interpretation of facts. A recent book on Hayek by Oxford philosopher John Gray has shown that Hayek's

\footnotetext{
${ }^{31}$ See, for example, the ongoing debate between the anti-equilibrium and the anti-nihilist factions in the first volumes of the Austrian Economics Newsletter.
} 
epistemological perspective is broadly consistent with the very aspects of the epistemological contributions of Ludwig Wittgenstein, Michael Polanyi and others that were elaborated in the previous section. ${ }^{32}$

But what of Ludwig von Mises, the controversial proponent of "extreme apriorism"? As usually interpreted, for example, by Hutchison, Mises saw economic theory as a kind of privileged body of what Mises himself sometimes called apodictically certain knowledge that was "strictly deduced" from a small number of "axioms" in much the same way Euclidean geometry is thought to be unambiguously and exhaustively generated from a fixed set of axioms. In fact, many mathematicians would deny that even geometry or mathematics in general are strict axiomatic systems in this sense, but most economists would agree that their discipline is no such thing. And certainly if this is what Mises meant by praxeology he can be accused of the very foundationalism that the growth of knowledge and hermeneutics traditions teach us we must transcend. Indeed, he has been so criticized directly by one of the leading growth of knowledge contributors, Imre Lakatos (1978, p. 10) and this criticism has been enthusiastically seconded by Hutchison (1981, p. 294, 303). Even such close followers of Mises as Hayek have dissociated themselves from this extreme apriorism.

The purpose of this section will be not to subject this common Euclidean interpretation of Mises to detailed criticism but to show that an entirely different interpretation is possible, one that has Mises looking remarkably similar to the contributors to the growth of knowledge and hermeneutics traditions. ${ }^{33}$

Now it is true that Mises in many passages characterizes his own methodology as "axiomatic" and "strictly deductive" and "independent" of historical facts. But it is more important to see how a scholar actually proceeds in his own work than to listen to him articulate his explicit methodology.

First of all it has to be mentioned that Mises was deeply influenced by Dilthey and Weber and it was exactly this hermeneutical school in the philosophy of the social sciences upon which he depended entirely for his views on the proper tasks of the historian including the economic historian. He said that "first, Dilthey, then Windelband, Rickert, Max Weber, Croce and Collingwood . . . succeeded brilliantly in elucidating the epistemological features of the study of history," an accomplishment Mises called "one of the most important contributions of modern epistemology." 34

There is a widespread impression among economists, for which Mises himself is partly to be blamed, that he wanted to strictly dichotomize theory from history. Professor Seligman (1971, p. 330), just to give one example, went so far as to say that Mises "blithely cast out historical investigation of economic phenomena", "fought heroically to keep . . . history out of economics," and "insisted that such approaches reflected only the personality and bias of the writer." In fact, however, the methods he actually used and many of the arguments he offers on their behalf indicate that Mises thought of praxeology as a "scheme of interpretation" (1966,

\footnotetext{
32 See Hayek (1952; 1967; 1978a; 1978b) and Gray (1984).

33 Space does not permit elaborating on these alternative interpretations of Mises's apriorism in this paper.

${ }^{34}$ Mises (1966, p. 50). During a semester toward the end of World War I Weber visited Vienna and, Mises wrote, they "became good friends," (1978, p. 70). Schutz was a good friend of Mises for many years in New York City and had been a regular participant in Mises's private seminar in Vienna.
} 
p. 26) that was both shaped by and illuminative of history. Economic theory needed to be applied as an interpretive scheme to the explication of real historical circumstances, in order to yield its intellectual fruits. For Mises, as for the growth of knowledge writers, theory is a device through which we see facts of the historical world. As will be argued below, Mises saw theory and history as two complementary halves of the human sciences either of which, alone, is fundamentally incomplete. ${ }^{35}$

Echoing the themes of hermeneutics, Mises criticized those who refuse to comprehend human action "as meaningful and purposeful behavior." It is impossible "to grasp human action intellectually... without entering into the meaning which the acting parties attribute to the situation" (1966, p. 26). One cannot, as Geertz had said, study witchcraft as a geometer. The way Mises describes the earliest realization that there are regularities in economic phenomena is that people discovered that "there is another aspect from which human action might be viewed than that of good and bad, of fair and unfair, of just and unjust" (1966, p. 2). Mises views his economic theory as providing us with a workable scheme for the subjective interpretation of human conduct, and one which is not the only such perspective possible. As Mises (1978, p. 71), put it,

What we know about our own actions and about those of other people is conditioned by our familiarity with the category of action that we owe to a process of self- examination and introspection as well as of understanding of other peoples' conduct. To question this insight is no less impossible than to question the fact that we are alive.

As Schutz argued, those who try to suspend judgment on whether other minds are intelligent will in any case contradict themselves in practice by arguing their behavioralistic case to other "minds" in the scientific community. For Mises, as for Schutz, the starting point of the investigation of society is a reflection on the alreadyinterpreted life-world, the world of human action in practical everyday experience. "We must bethink ourselves and reflect upon the structure of human action. Like logic and mathematics, praxeological knowledge is in us; it does not come from without" (Mises 1966). In calling his method "aprioristic," Mises uses the language of Kantian philosophers and often compares praxeology with logic and mathematics, but he does not attempt to supply any sort of metaphysical or ontological "foundation" for his apriorism. Instead, he relies on a pragmatic argument, saying simply that circumstances enjoin upon us not a metaphysical but a "methodological apriorism" (1966, p. 35):

Everybody in his daily behavior again and again bears witness to the immutability and universality of the categories of thought and action. $\mathrm{He}$ who addresses fellow men, who wants to inform and convince them, who asks questions and answers other people's questions, can proceed in this way only because he can appeal to something common to all men... (1966, p. 36).

\footnotetext{
35 This view of the complementarity of theory and history elevates the significance of Mises's endorsement of Dilthey on the methods appropriate to history.
} 
We must accept not only the existence but also the significance of the alreadyinterpreted life-world or involve ourselves in self-contradiction. We accept the assumption that we share an intersubjectivity with one another not because of philosophical "foundations" but because this procedure works in everyday life and in science. Mises says the emptiness of objectivism, or as he says "positivism," becomes manifest "precisely when we accept this pragmatic point of view" (1966, p. 24).

In a passage to which a reference to Schutz (1932) is attached, Mises shows that his defense of the validity of the "apriori" is the same as the hermeneutical defense: practically speaking all of us are already taking the life-world for granted. A priori propositions, such as that all humans share the same commonsense logic, are to be employed because they are already in extensive use and they "work in practice and in science":

[T] he positivist must not overlook the fact that in addressing his fellow men he presupposes - tacitly and implicitly - the intersubjective validity of logic and thereby the reality of the alter Ego's thought and action, of his eminent human character (1966, p. 24).

Even "regular citizens eager to comprehend occuring changes" resort to an aprioristic approach in this sense. Any debate about human affairs "inevitably turns away from the accidental and environmental features of the event concerned to an analysis of fundamental principles, and imperceptibly abandons any reference to the factual happenings which evoked the argument." Reflection on human events invariably leads us in the direction of conceptually isolating different features of the already-interpreted life-world. Theory is the way we capture meanings that are already there in the practical world, it is not simply a set of hypotheses over which the facts of history unilaterally dominate.

The truth is that the experience of a complex phenomenon-and there is no other experience in the realm of human action - can always be interpreted on the ground of various antithetic theories. Whether the interpretation is considered satisfactory or unsatisfactory depends on the appreciation of the theories in question established beforehand on the ground of aprioristic reasoning (1966, p. 41).

Without the "schemes provided by praxeological reasoning," Mises contends, "we would perceive motions, but neither buying nor selling, nor prices, wage rates, interest rates, and so on." Mises is no more or less an apriorist than each of us is in his everyday life. For all of us, if we lacked "such preexisting knowledge" as what a medium of exchange is, we would see in coins "only round plates of metal, nothing more" (1966, p. 40).

"The intellectual methods of science," says Mises, "do not differ in kind from those applied by the common man in his daily mundane reasoning" except that the scientist uses the layman's tools "more skillfully and cautiously" (1966, p. 58). As with the growth of knowledge and hermeneutics traditions, Mises held that "Reasoning and scientific inquiry can never bring full ease of mind, apodictic certainty, and perfect cognition of all things" (1966, p. 25). Man, he admits, can never be certain and therefore although Mises sometimes calls the a priori 
apodictically certain, even it cannot be beyond criticism. "All that man can do is to submit all his theories again and again to the most critical re-examination" (1966, p. 68).

And if we look in Mises's writings for his recommendations for specific methods of economic analysis, we find that instead of urging the construction of a string of tightly connected logical or mathematical theorems, he recommends an open-ended, virtually unrestrained procedure for exercising the human imagination. One would expect of a true Euclidean nothing less than a formal mathematical system, yet as is well-known Mises's work is conspicuous in twentieth century economics for its avoidance of mathematics or formal modeling, and he even argued that economics is not primarily a quantitative science, even though numbers (in the form of money prices) are among the central phenomena to be explained.

Numbers applied by acting man in economic calculation do not refer to quantities measured but to exchange ratios as they are expected - on the basis of understanding - to be realized on the markets of the future to which alone all acting is directed and which alone counts for acting man.

We are not dealing... with the problem of a "quantitative science of economics", but with the analysis of the mental processes performed by acting man in applying quantitative distinctions when planning conduct (1966, p. 210). ${ }^{36}$

The specific method of praxeology is not formal logic or mathematics but what he calls "the method of imaginary constructions." Again Mises tells us this is not what he thinks ought to be the method but it is and has been the main method people have used. "Everyone who wants to express an opinion about the problems commonly called economic takes recourse to this method," the scientist only elaborating his imaginary constructions with more care, precision, and criticism than the layman (1966, p. 236).

An imaginary construction is a conceptual image of a sequence of events logically evolved from the elements of action employed in its formation. It is a product of deduction, ultimately derived from the fundamental category of action, the act of preferring and setting aside. In designing such an imaginary construction the economist is not concerned with the question of whether or not it depicts the conditions of reality which he wants to analyze. Nor does be bother about the question of whether or not such a system as his imaginary construction posits could be conceived as really existent and in operation. Even imaginary constructions which are inconceivable, self-contradictory, or unrealizable, can render useful, even indispensable services in the comprehension of reality, provided the economist knows how to use them properly (1966, p. 236).

Here again Mises relies on a pragmatic rather than foundationalist defense of this "method," stating simply that it is "justified by its success." While Mises is as usual

\footnotetext{
${ }^{36}$ Mises may, however, have put things a bit too harshly when he called mathematical economics "an entirely vicious method, starting from false assumptions and leading to fallacious inferences" (1966, p. 350).
} 
inclined to exaggerate the unique usefulness of this method of mental experimentation for praxeology, ${ }^{37}$ he cannot be faulted for forcing economics into any strict methodological mould. The "method" of imaginary constructions is an unbounded mode of speculative discourse and reflection which has already proven capable of generating insight in traditional economics. The only "formula" Mises recommends for designing these mental images is "to abstract from the operation of some conditions present in actual action" in order to "grasp the hypothetical consequences of the absence of these conditions and to conceive the effects of their existence" (1966, p. 237). In short, we use our imaginations. We talk about Crusoes and equilibriums and utopias without scarcity and all manner of other fictions in order to clarify our thoughts about exchange economies, processes of change, problems of allocation, etc. In lieu of any particular procedural rules, Mises offers the economist a general warning that the method "can easily result in fallacious syllogism" and so must be used with "merciless self-criticism" (1966, p. 237). It would be difficult to find methodological rules advanced by any economist that are more in the spirit of the growth of knowledge and hermeneutics traditions than this. But if this account of Mises's open-ended, hermeneutical conception of theory is correct, then why do so many writers, from Hutchison to Seligman, read him as dichotomizing theory from history? We should recall that Mises became aware of methodology at a time and place where the very possibility of a theoretical science of human affairs was considered highly questionable. This was especially true among historians, who under the influence of the German historical school saw the human sciences as involving a theory-less gathering and recording of facts. To oppose this view, Mises frequently emphasized that there is a legitimate cognitive contribution to be made by the kind of reflective theorizing described above, as distinct from the attention to particulars that is the proper domain of history. Combined with his combative style Mises's insistence on the difference between theory and history has led to the mistaken view that he wanted to separate them.

There is a distinction between asking the question "What happened?" and asking the question "What can happen?" and in fact to answer the historical question will entail making some implicit or explicit decisions about the theoretical one. It is inappropriate for the historian to interrupt the economist, before, say, Crusoe is finished making his net, to insist that early man lived in society, not alone. Economic theorists, insisted Mises, are asking a different kind of question. An historical debate, as Mises says, "inevitably turns" to a discussion about "fundamental principles." Thus, we must reserve a legitimate domain of scientific attention to the use of our speculative imagination, to the contemplation of imaginary constructions. In fact, since this is already done tacitly by the most historicist historian, we may as well acknowledge what it is we are all doing. But today's intellectual environment tends

\footnotetext{
${ }^{37}$ Mises takes a rather extreme methodological dualist position calling the method of praxeology "entirely different" from those of physics and biology (1966, p. 237). And yet he admits to some close parallels between the biologist's analysis of what he calls "quasi-action," i.e., instinctual behavior, and the praxeologist's study of human action (1966, pp. 27-28). See Hayek (1967) and Polanyi (1958b) for a more defensible methodological position which could be called a methodological dualism-by-degree. Fundamental processes of persuasion are common to all the sciences, but they vary from the least complex and most remote from ourselves on the natural science end, toward the most complex and closest to ourselves, on the social science end, with sciences like biology occupying a middle ground.
} 
more to denigrate history than theory. To the extent that economic theory is pursued in the contemporary journals at all, it is pursued as an exercise that makes no reference to the "concrete historical and political problems" from which Mises thought theory should never be strictly separated (1966, p. 66). Facing this kind of audience Mises would have probably argued as vigorously for the mutual dependence of theory and history as he has argued against the historicists that each has its own distinctive aims and procedures.

Moreover, if Mises's intention was to exorcise history from economics why did he permit the form of his own economic discourse to be one in which "theory and the interpretation of historical phenomena are intertwined"? All Mises's books are filled with historical detail. Does this not needlessly clutter up the strictly deductive reasoning?

Mises must have considered theory and history as inherently connected and not just connected in the form in which economics usually happens to be presented. Each, theory and history, is fundamentally incomplete without the other. Theory "does not convey to us full cognition of reality" although without it "there is no comprehension of the reality of human action." Theory and history "are not in opposition to one another" but are two complementary aspects of cognition (1966, pp. 38-39). History moulds the direction of theoretical investigation, while theory is used as the interpretive framework with which the specific historical narratives can be told. The conception of "What can happen?" that we bring with us to an historical episode shapes the way we will work over the evidence as we ask the question "What did happen?" At the same time, the questions as to "What did happen?" influence the agendas of economists about which, of the infinite number of specific "What can happen?" questions he might be able to conjure up, are worthy of his serious attention.

Mises's discussion of history, like that of the Gadamer strand of the hermeneutics tradition, stresses that history always is and should be guided by enabling presuppositions derived from theory, including but not confined to the a priori theory that comes from reflection on the life-world.

History is not an intellectual reproduction, but a condensed representation of the past in conceptual terms. The historian does not simply let the events speak for themselves. He arranges them from the aspect of the ideas underlying the formation of the general notions he uses in their presentation. He does not report facts as they happened, but only relevant facts. He does not approach the documents without presuppositions, but equipped with the whole apparatus of his age's scientific knowledge, that is, with all the teachings of contemporary logic, mathematics, praxeology, and natural science (1966, pp. 47-48).

In short, as Gadamer stresses, understanding can never entail trying to see events exclusively from the point of view of the interpreted but must be informed by the intellectual equipment of the interpreter. Mises (1966, pp. 50-51) illustrates his argument by pointing out that a modern historian of the middle ages would not be justified in attributing causal agency to "the devil" even though all his historical "witnesses" agree with one another that the devil was responsible. Since this "fact" violates our contemporary views of what can happen, the historian must question the fact and try to reconstruct what must have really happened in spite of his witnesses' 
unanimity. As Geertz had said, we don't want an ethnography of witchcraft as written by a witch. Similarly the modern economist would properly view witnesses' reports that a particular inflation was caused by a fall in the money supply as unreliable. Economic reasoning tells us this cannot be.

Thus Mises allows that "history can never be studied without presuppositions" and that "dissension with regard to the presuppositions" must be the basis for the establishment of historical facts (1966, p. 53). This means that as science progresses and the presuppositions change this entails a continuous "rewriting of history."

Every generation must treat anew the same historical problems because they appear to it in a different light. The theological world view of older times led to a treatment of history other than the theorems of modern natural science. Subjective economics produces historical works very different from those based on mercantilist doctrine (1966, pp. 53-54).

But though history is dependent on theoretical presuppositions, so is theory dependent on history in at least two ways. First, the development of theory in some directions rather than others is dependent on the problems posed by our prior understanding of history. And second, the acceptance or rejection of a theory depends on the usefulness with which it serves as a device for interpreting history. Mises explicitly accepted the first point when he argued that theoretical invention has to be guided by considerations of at least indirect relevance to real historical circumstances.

It might be conceivable, Mises points out, to invent mental experiments for all conceivable historical circumstances "by delineating all thinkable conditions and deducing from them all inferences logically permissible." But for Mises "the end of science is to know reality ... not mental gymnastics." Or as Gadamer (1976, p. 11) says, "there is such a thing as methodological sterility." Hence, Mises says that praxeology "restricts its inquiries to the study of acting under those conditions and presuppositions which are given in reality." Unrealizable conditions should be imagined "if such an inquiry is needed for a satisfactory grasp of what is going on under the conditions present in reality" (1966, p. 65), while Mises's methods are not strictly rule-governed (objectivistic) they are also not completely unguided (relativistic). Theoretical speculation should be directed to the reality that needs interpreting.

On the second point Mises is less clear, but he can be read as endorsing the position that the reason we accept an interpretive framework is that we believe we "see" history better through it than through alternative frameworks. Mises held that the whole purpose of theory is to "render useful services for the comprehension of reality" (1966, p. 66). For Mises then, the value of theory is a derived demand. What a theory is worth depends on how well it "works," that is, how good a grasp on the events of reality it enables its user to attain. In the weighing of the usefulness of a theory for interpreting history that theory is "tested" in the only way a theory ever is.

Returning to Caldwell's question about theory choice, if a priori theories seem capable of multiplication, how are we to choose one over another? Mises's answer would appear to be no different from that of the growth of knowledge and hermeneutics traditions. The only way one can choose among interpretive frameworks is to try to see reality through them, one by one, to try to debate where 
disagreements seem crucial, and ultimately, to make a judgment about which perspective renders the best grasp on the flow of events. In arguing for the aprioristic method, Mises was not claiming special validity to his own particular development of aprioristic theory, much less his own understanding of history, but was trying to echo the hermeneuticists' point that all social theorists in practice and each of us in our everyday lives view social phenomena as already interpreted, or from within. Although he emphasized differences between theory and history, he did not wish to, and did not himself, dichotomize them. He insisted, as both the growth of knowledge and hermeneutics literatures do, that theories are frameworks for the interpretation of the facts of history, more than hypotheses to be tested by those facts. Nevertheless, there is no way to be certain in life that one's own interpretive perspective is the best. This need not imply relativism, but only reinforces the fact that our only way to eliminate errors is to submit our own and our fellows' work, as Mises puts it, "to the most critical re-examination."

The problem of theory choice can be "solved" not algorithmically but intersubjectively; not logically within one mind but dialogically among several. Adherents of alternative interpretive frameworks must endeavor to make their statements more intelligible to one another, to interpret one another's meaning, to pose one another's problems, to persuade one another. Through a spontaneous interplay of mutual criticism, a kind of tug of war of rivalrous interpretations, the evolution of knowledge can continue to be progressive, so long as enough of its participant minds remain genuinely committed to discovering the truth. To the objectivist, of course, this seems to be no real solution of the problem of theory choice. We can point to no objective technique which could be used to tell us how we can select better interpretive frameworks out of the multitude of candidates. Instead it is left to be solved anonymously, and continuously, by the critical process of controversy that can occur among people who commit themselves to the pursuit of knowledge.

Before the 1930s, the history of economics exhibited, for the most part, just this sort of tumultuous rivalry of mutual interpretations and criticisms. Lively debates among diverse perspectives were the staple diet of subscribers to the professional journals. This was not, as we are often told in contemporary textbooks, merely an unfocussed blur of opinions from which mathematics has saved us. Substantial progress had been occurring in political economy for 150 years, not least of which was the marginalist/subjectivist revolution itself. That revolution, the Keynesian revolution, and numerous other analytical skirmishes were underway in lively discourse when social sciences came under the grip of objectivism. Subjectivist micro and Keynes's macro were both reduced to increasingly formal modes of expression and were transformed into rarified equilibrium theory, constrained maximization problems, and the IS/LM model. A couple generations of economists became imbued with objectivist methodology and allowed this to interfere with the natural development of the science. Interpretive appeal of purported scientific explanations was systematically devalued in favor of mathematical elegance in theoretical work and in favor of quantitative accuracy in empirical work. Economics was to become a strict, quantitative science and its language was to become mathematics. Mises, stubbornly sticking to his outmoded "literary" style, was one of the victims of his profession's infatuation with formalism. His early dismissals of 
mathematical economics as "sterile" probably sounded shrill at the time, and may have been premature. But a growing number of economists today would be willing to admit, after seeing the fruits of the development of economics in formalistic directions for fifty years, that he was right when he said formalism would "divert the mind from the study of real problems" (1966, p. 350).

Of course economists thought that this "rigorization" of their science would end the contention among divergent schools and settle many old disputes. What we see in fact is that radically divergent schools remain and that the disputes were not resolved but dissolved and forgotten. What has been lost, besides the sheer fun of economic controversies, has been the very force that propelled progress in our science.

\section{References}

Austin, J. (1962). How to do things with words. Cambridge: Harvard University Press.

Barnes, B. (1982). T. S. Kuhn and social science. New York: Columbia University Press.

Barrett, W. (1979). The illusion of technique. Garden City: Anchor Press.

Berlin, I. (1969). A note on Vico's concept of knowledge. In G. Tagliacozzo et al. (Eds.), Giambattista Vico: An international symposium (pp. 371-377). Baltimore: Johns Hopkins University Press.

Bernstein, R. J. (1983). Beyond objectivism and relativism: Science, hermeneutics, and praxis. Philadelphia: University of Pennsylvania Press.

Bleicher, J. (1980). Contemporary hermeneutics: Hermeneutics as method, philosophy and critique. Boston: Routledge and Kegan Paul.

Caldwell, B. (1982). Beyond positivism: Economic methodology in the twentieth century. Boston: Allen and Unwin.

Collingwood, R. G. (1946). The idea of history. New York: Oxford University Press.

Dewey, J. (1929). The quest for certainty: A study of the relation of knowledge and action. New York: Minton, Balch and Co.

Dilthey, W. (1976). Selected writings, edited, translated and introduced by H. P. Rickman. New York: Cambridge University Press.

Earl, P. E. (1983). The economic imagination: Towards a behavioral analysis of choice. Brighton: Harvester Press).

Ebeling, Richard M. (1985) Hermeneutics and the interpretive element in the analysis of the market process. Center for the Study of Market Processes Working Paper \#16, George Mason University.

Feyerabend, P. (1975). Against method: Outline of an anarchistic theory of knowledge. London: Verso Editions.

Ford, J. L. (1983). Choice, expectation and uncertainty: An appraisal of G. L. S. Shackle's theory. Oxford: Martin Robertson.

Gadamer, Hans-Georg (1960) Wahrheit and Methode: Grundzuge Einer Philosophischen Hermeneutik (Tubingen: Mohr) translated as Gadamer (1975a).

Gadamer, H.-G. (1975a). Truth and method, translated and edited by Garrett Barden and John Cumming. New York: Seabury Press.

Gadamer, H.-G. (1975b). Hermeneutics and social science. Cultural Hermeneutics, 2, 307-316.

Gadamer, H.-G. (1976). Philosophical hermeneutics, translated and edited by David E. Linge. Berkeley: University of California Press.

Gadamer, Hans-Georg (1982) Reason in the age of science, translated by F.G. Lawrence. Cambridge, MA: MIT Press.

Geertz, C. (1973). The interpretation of cultures. New York: Basic.

Geertz, C (1979) From the native's point of view: On the nature of anthropological understanding. In Rabinow and Sullivan (eds) Interpretive social science: A reader. Berkeley, CA: University of California Press

Gelwick, R. (1977). The way of discovery: An introduction to the thought of Michael Polanyi. New York: Oxford University Press.

Gier, N. F. (1981). Wittgenstein and phenomenology: A comparative study of the later Wittgenstein, Husserl, Heidegger and Merleau-Ponty. Albany: State University of New York Press. 
Gray, J. (1984). Hayek on liberty. Oxford: Basil Blackwell.

Grinder, W. E. (1977). "In Pursuit of the Subjective Paradigm," introduction to L. M. Lachmann (1977) Capital expectations and the market process: Essays on the theory of the market economy. Kansas City: Sheed Andrews and McMeel.

Gurwitsch, A. (1974). Phenomenology and the theory of science. Evanston: Northwestern University Press.

Hahn, F., \& Hollis, M. (Eds.). (1979). Philosophy and economic theory. New York: Oxford University Press.

Hattiangadi, J. N. (1983). A methodology without methodological rules. In R. S. Cohen \& M. W. Wartofsky (Eds.), Language, logic, and method (pp. 103-151). Dordrecht, Holland: D. Reidel.

Hayek, F. A. (1952). The sensory order. Chicago: University of Chicago Press.

Hayek, F. A. (1967). Studies in philosophy, politics, and economics. Chicago: University of Chicago Press.

Hayek, F. A. (1978a). New studies in philosophy, politics, economics and the history of ideas. Chicago: University of Chicago Press.

Hayek, FA (1978b) The primacy of the abstract, in Hayek (1978a) pp. 35-49

Heelan, P. (1983a). Natural science as a hermeneutic of instrumentation. Philosophy of Science, 50, 181204.

Heelan, F. A. (1983b). Perception as a hermeneutical act. Review of Metaphysics, 37, 61-75.

Hesse, M. (1980). Revolutions and reconstructions in the philosophy of science. Brighton: Harvester Press.

Hey, J. D. (1984). Unshackling economics. Scottish Journal of Political Economy, 31(2), 202-208.

Hirsch, E. D., Jr. (1967). Validity in interpretation. New Haven: Yale University Press.

Hollis, M., \& Nell, E. J. (1975). Economic man: A philosophical critique of neo-classical economics. New York: Cambridge University Press.

Howard, R. J. (1982). Three faces of hermeneutics: An introduction to current theories of understanding. Berkley: University of California Press.

Husserl, E. (1962). Ideas; general introduction to pure phenomenology. New York: Collier.

Hutchison, T. W. (1981). The politics and philosophy of economics, Marxians, Keynesians and Austrians. New York: New York University Press.

Ihde, D. (1971). Hermeneutic phenomenology: The philosophy of Paul Ricoeur. Evanston: Northwestern University Press.

Ions, E. (1977). Against behavioralism: A critique of behavioral science. Oxford: Basil Blackwell.

Kay, N. M. (1984). The emergent firm: Knowledge, ignorance and surprise in economic organization. London: Macmillan.

Kuhn, T. S. (1970). The structure of scientific revolutions, 2nd Edition. Chicago: University of Chicago Press.

Kuhn, T. S. (1976). Theory-change as structure-change: Comments on the Sneed formalism. Erkenntnis, 10, 179-199.

Kuhn, T. S. (1977). The essential tension: Selected studies in scientific tradition and change. Chicago: University of Chicago Press.

Lachmann, L. M. (1971). The legacy of Max Weber. Berkeley: Glendessary Press.

Lachmann, Ludwig M. (1984) Economic theory in tempestuous season (unpublished English translation by Cornelia Dorfschmid) copyright by Frankfurter Allgemeine Zeitung.

Lakatos, I. (1978). Mathematics, science and epistemology. New York: Cambridge University Press.

Lakatos, I., \& Musgrave, A. (1970). Criticism and the growth of knowledge. New York: Cambridge University Press.

Langlois, RN and Koppl RG (1984) Fritz Machlup and marginalism: A re-evaluation. Center for the Study of Market Processes Working Paper \#14.

Lauer, Q. (1965). Phenomenology; its genesis and prospect. New York: Harper and Row.

Lavoie, D. (1977). From Hollis and Nell to Hollis and Mises. Journal of Libertarian Studies, 1(4), 325336.

Lavoie, D. (1985a). Rivalry and central planning: the socialist calculation debate reconsidered. New York: Cambridge University Press.

Lavoie, D. (1985b). National economic planning: What is left? Cambridge: Ballinger.

Leijonhufvud, A. (1981). Information and coordination: Essays in macroeconomic theory. New York: Oxford University Press.

Levy, D. J. (1981). Realism: An essay in interpretation and social reality. Manchester: Carcanet New Press). 
Linge, DE (1976) Editor's introduction. In Gadamer H-G (ed) Philosophical Hermeneutics, translated and edited by David E. Linge. Berkeley: University of California Press.

Luckmann, T. (Ed.). (1978). Phenomenology and sociology: Selected readings. New York: Penguin.

Luckmann, T. (1981). Hermeneutics as a paradigm for social science? In M. Brenner (Ed.), Social method and social life. New York: Academic Press.

McCloskey, D. N. (1983). The rhetoric of economics. Journal of Economic Literature, 21, 481-517.

Merleau-Ponty, M. (1962). Phenomenology of perception, trans. by Colin Smith. London: Routledge and Kegan Paul.

Merleau-Ponty, M. (1964). The primacy of perception. Evanston: Northwestern University Press.

von Mises, L. (1966). Human action: A treatise on economics, 3rd revised edition. Chicago: Regnery.

von Mises, L. (1978). The ultimate foundation of economic science: An essay on method. Kansas City: Sheed Andrews and McMeel.

von Mises, L. (1981). Epistemological problems of economics translated by George Reisman. New York: New York University Press.

Natanson, M (1973) Phenomenology and the social sciences, 2 volumes. Evanston: Northwestern University Press.

O'Driscoll, G. P., Jr., \& Rizzo, M. J. (1985). The economics of time and ignorance. New York: Columbia University Press.

Polanyi, M. (1958a). Personal knowledge towards a post-critical philosophy. Chicago: University of Chicago Press.

Polanyi, M. (1958b). The study of man. Chicago: University of Chicago Press.

Polanyi, M. (1969). Knowing and being edited by Marjorie Grene. Chicago: University of Chicago Press.

Polanyi, M (1972) Genius in science, Encounter (January).

Polanyi, M., \& Prosch, H. (1975). Meaning. Chicago: University of Chicago Press.

Polkinghorne, D. (1983). Methodology for the human sciences: Systems of inquiry. Albany: SUNY Press.

Popper, K. R. (1964). The poverty of historicism. New York: Harper and Row.

Popper, K. R. (1965). The logic of scientific discovery. New York: Harper and Row.

Popper, K. R. (1972). Objective knowledge: An evolutionary approach. New York: Oxford University Press.

Rabinow, P., \& Sullivan, W. M. (Eds.). (1979). Interpretive social science: A reader. Berkeley: University of California Press.

Randall, F (1984) Why scholars become storytellers, The New York Times Book Review (Jan 29).

Ricoeur, P. (1965). History and truth, translated by C.A. Kelbley. Evanston: Northwestern University Press.

Ricoeur, P. (1981). Hermeneutics and the human sciences, edited and translated by J. B. Thompson. New York: Cambridge University Press.

Rorty, R. (1979). Philosophy and the mirror of nature. Princeton: Princeton University Press.

Rothbard, M. N. (1973) Praxeology as the method of economics, in volume 2 of Natanson (1973), pp. 311-339.

Sayer, A. (1984). Method in social science: A realist approach. London: Hutchinson.

Schutz, A. (1932). The phenomenology of the social world. Vienna: Springer-Verlag.

Schutz, A. (1970). On phenomenology and social relations, edited and introduced by Helmut R. Wagner. Chicago: University of Chicago Press.

Schutz, A., \& Luckmann, T. (1973). The structures of the life-world. Evanston: Northwestern University Press.

Seligman, B. B. (1971). Main currents in modern economics, volume 2. The reaffirmation of tradition. Chicago: Quadrangle.

Simmel, G. (1980). Essays on interpretation in social science, translated, edited and introduced by Guy Oakes. Totowa: Rowan and Littlefield.

Strickland, G. (1981). Structuralism or criticism? Thoughts on how we read. New York: Cambridge University Press.

Taylor, C. (1964). The explanation of behavior. New York: Humanities Press.

Taylor, C. (1971). Interpretation and the sciences of man. Review of Metaphysics, 25, 3-51.

Taylor, C. (1980). Understanding in human science. Review of Metaphysics, 34, 25-38.

Toulmin, S. (1972). Human understanding: The collective use and evolution of concepts. Princeton: Princeton University Press.

Weber, M. (1949). The methodology of the social sciences, translated and edited by Edward A Shils and Henry A. Finch. New York: The Free Press. 
Weber, M. (1980). The interpretation of social reality, edited and introduced by J.E.T. Eldridge. New York: Schocken Books.

Weimer, W. B. (1980). For and against method: Reflections on Feyerabend and the foibles of philosophy. Pre/Text, 1-2, 161-203.

von Wieser, F. (1928). Social economics, translated by A. F. Hinrichs. London: Allen and Unwin.

Winch, P. (1958). The idea of a social science and its relation to philosophy. Highlands: Humanities Press International.

Wittgenstein, L. (1958). Philosophical investigations, 3rd edition. New York: Macmillan.

Zaner, R. M. (1974). A certain rush of wind: Misunderstanding understanding in the social sciences. Cultural Hermeneutics, 1, 383-402. 